\title{
LA DISTRIBUCIÓN DE RIESGOS EN LA EJECUCIÓN DE LOS CONTRATOS ADMINISTRATIVOS
}

\author{
GERMÁN FERNÁNDEZ FARRERES \\ Universidad Complutense de Madrid
}

\author{
Cómo citar/Citation \\ Fernández Farreres, G. (2021). \\ La distribución de riesgos en la ejecución \\ de los contratos administrativos. \\ Revista de Administración Pública, 216, 47-90. \\ doi: https://doi.org/10.18042/cepc/rap.216.02
}

\section{Resumen}

Estudio de la regulación legal de la distribución de riesgos en la ejecución de los contratos administrativos. La conclusión a la que se llega es que la vigente regulación resulta insuficiente y presenta algunas deficiencias. Convendría establecer con mayor precisión las excepciones posibles a la regla del riesgo y ventura del contratista, lo que permitiría, a su vez, acotar mejor los márgenes en los que se puede desenvolver la libertad de pactos como mecanismo complementario de la distribución de riesgos en la contratación pública. Con ello también se facilitaría la superación de una jurisprudencia en la que la apelación a principios generales para resolver las controversias resulta excesiva, lo que inevitablemente afecta a la seguridad jurídica.

\section{Palabras clave}

Contratos administrativos; riesgo y ventura; factum principis; fuerza mayor; riesgo imprevisible; ius variandi; equilibrio económico; libertad de pactos.

\section{Abstract}

Study of the legal regulation of risk distribution in the execution of administrative contracts. The conclusion reached is that the current regulation is insufficient and presents numerous deficiencies. It is necessary to establish with greater precision the possible exceptions to the rule of risk and fortune of the contractor, which would allow, in turn, to better limit the margins in which the freedom of agreements can be developed as a complementary mechanism of the distribu- 
tion of risks in public procurement. This would also facilitate the overcoming of a jurisprudence in which the appeal to general principles to resolve disputes is excessive, which inevitably affects legal certainty.

\section{Keywords}

Administrative contracts; risk and luck; factum principis; overwhelming force; unforeseeable risk; ius variandi; economic equilibrium; freedom of pacts. 


\section{SUMARIO}

I. INTRODUCCIÓN. II. LA REGLA GENERAL DEL RIESGO Y VENTURA DEL CONTRATISTA EN LA EJECUCIÓN DE LOS CONTRATOS ADMINISTRATIVOS. III. EXCEPCIONES A LA REGLA DEL RIESGO Y VENTURA DEL CONTRATISTA: 1. Fuerza mayor. 2. «Actuaciones» de la Administración contratante que alteran la equivalencia de las prestaciones. El limitado alcance del factum principis. 3. La obligación de incorporar avances técnicos que mejoren la prestación del servicio. IV. RIESGO Y VENTURA DEL CONTRATISTA ANTE RIESGOS IMPREVISTOS E IMPREVISIBLES. V. RIESGO Y VENTURA DEL CONTRATISTA ANTE EL EJERCICIO DE PODERES CONTRACTUALES DE LA ADMINISTRACIÓN. VI. LIBERTAD DE PACTOS Y ASIGNACIÓN DE RIESGOS.VII. CONCLUSIONES.

\section{INTRODUCCIÓN}

La asignación de riesgos en la ejecución de los contratos es asunto de capital importancia. Del acierto en la previsión de las contingencias que, ajenas a la propia conducta de las partes contratantes, pueden acaecer en el curso del cumplimiento de las obligaciones contraídas, dependerá que sus respectivos intereses y el fin que les lleva a contratar queden debidamente satisfechos.

La previsión de riesgos se enfrenta a no pocas dificultades. Múltiples son los hechos y circunstancias a tener en cuenta. Su catalogación en abstracto siempre es factible - riesgo regulatorio, riesgo financiero, riesgo técnico, riesgo de responsabilidad por perjuicios causados a terceros, riesgo de insolvencia, riesgo de demanda, riesgo de suministro, riesgo vinculado a la producción de fenómenos naturales, etc. ${ }^{1}$ - , aunque, como es evidente, el problema radica en poder o saber concretarlos ante cada caso. Una concreción que realizan los contratantes en fun-

1 Una sistematización de los riesgos, atendiendo a los diversos supuestos que integran el triple áleas que pesa sobre el contratista, en G. Ariño Ortiz (1968), Teoría del equivalente económico en los contratos administrativos, Madrid: Instituto de Estudios Administrativos, págs. 6 y 162 ss.; también R. Sahún Pacheco (2019), Riesgo operacional y servicio público, Madrid: BOE, págs. 25 ss. 
ción de lo que estiman previsible o razonable que suceda y, desde luego, contando siempre con las reglas que se aplicarán en el supuesto de que el riesgo no previsto llegue a hacerse efectivo.

Las normas de distribución y asignación de los riesgos no previstos eliminan formalmente la incertidumbre. Se ignorará, ciertamente, si los mismos llegarán a producirse y, desde luego, cuál será la cuantificación de sus consecuencias, pero al menos no se desconocerá quién tendrá que asumirlos. Cualquiera que sea el motivo de la imprevisión — desde su imposible predicción a la consideración de la muy escasa probabilidad de que se pueda producir-, el riesgo quedará mitigado si la correspondiente norma dispone a qué contratante se imputarán los resultados económicos adversos que del mismo se puedan derivar.

Fácilmente se comprende la trascendencia de tales reglas. Según sean unas u otras, la contratación se facilitará o, por el contrario, la articulación y composición de los respectivos intereses se hará más costosa. Hasta el éxito o fracaso de la propia ejecución del contrato queda sujeto a su influjo. Las reglas de asignación de riesgos previstas por la ley terminan siendo, en definitiva, un punto neurálgico de toda contratación.

Por otra parte, la fijación de esas reglas puede verse condicionada por la cualidad de los intereses públicos o privados concurrentes en la contratación. A un sistema legal de asignación de riesgos no puede serle ajena la naturaleza de esos intereses. Ni tampoco ha de serle indiferente la eficacia que se asigne a tales reglas, siempre en función del margen de disposición que se pretenda otorgar a las partes contratantes. Como en tantas otras ocasiones, resulta necesario reflexionar sobre si una misma respuesta para realidades en parte distintas - como es el caso de la contratación pública y la contratación privada - es lo más adecuado o si, por el contrario, se requieren reajustes o modulaciones en atención a las peculiaridades de cada caso.

Sirva este breve apunte para enmarcar la finalidad perseguida con el presente trabajo. Se trata, fundamentalmente, de aclarar dos cuestiones previas y, tras ello, con arreglo a las conclusiones que se alcancen, de valorar en qué medida resulta satisfactorio el vigente sistema legal de reparto o asignación de riesgos en la contratación pública. Y es que, por sorprendente que sea, en las continuas reformas de la legislación contractual que se vienen sucediendo, más allá del parcial retoque que llevó a cabo la Ley 13/2003, de 23 de mayo, del Contrato de Concesión de Obras Públicas, y de la prohibición de la transferencia a la Administración del riesgo operacional en las concesiones de obras y de servicios que por imperativo comunitario ha dispuesto la vigente Ley de 2017, las reglas relativas a la asignación de riesgos vienen manteniéndose prácticamente invariables desde la inicial Ley de Contratos del Estado de 1965. Estamos, pues, ante un ejemplo claro de lo que ya ha sido advertido en otras ocasiones. Como dijera J. A. Santamaría Pastor, a la altura de 2014, a la sinrazón de tan continuas reformas de la legislación contractual por ser en muy buena medida innecesarias, se une el hecho de que dejan al margen aspectos esenciales del régimen de la contratación pública verdadera- 
mente necesitados, estos sí, de una adecuada reforma ${ }^{2}$. No otro es el caso —añado yo- de la cuestión que ahora nos ocupa.

Las cuestiones que considero necesario clarificar son las dos siguientes.

En primer lugar, la relativa al contenido de las reglas de reparto de riesgos que la legislación contractual vigente sanciona y, asimismo, la interpretación y aplicación judicial que de las mismas se viene haciendo. Pudiera suceder que, a la vista de esa aplicación - y no digamos ya, atendiendo a lo que la doctrina suele explicar-, se constate la existencia de desviaciones importantes entre lo previsto y lo que en la práctica acontece.

Y, en segundo lugar, conocido el régimen legal de asignación de riesgos, resulta también necesario aclarar cuándo ese régimen es de obligado cumplimiento o, por el contrario, meramente dispositivo, y, por tanto, cuál es el margen del que goza la Administración para desvincularse del mismo. $\mathrm{O}$, dicho en otros términos, qué posibilidades brinda el reconocimiento legal de la libertad de pactos para que las reglas previstas sean alteradas o moduladas.

Aclaradas estas dos cuestiones previas, mejor se podrá valorar si la situación actual necesita de alguna corrección legal.

\section{LA REGLA GENERAL DEL RIESGO Y VENTURA DEL CONTRATISTA EN LA EJECUCIÓN DE LOS CONTRATOS ADMINISTRATIVOS}

Desde las iniciales normas reguladoras de la contratación administrativa de obras públicas y los primeros pliegos de condiciones del siglo XIX, se viene repitiendo que la ejecución del contrato se realiza «a riesgo y ventura del contratista».

En la actualidad, el art. 197 LCSP la sanciona respecto de cualesquiera contratos administrativos y el art. 254 LCSP, específicamente para el contrato de concesión de obras, la reitera en su párrafo $1^{\circ}$. Una regla cuyo significado y alcance puede resumirse de la siguiente forma.

En primer lugar, la jurisprudencia viene repitiendo de manera constante, en expresión estereotipada, que "el riesgo y ventura del contratista ofrecen en el lenguaje jurídico y gramatical la configuración de la expresión riesgo como "contingencia o proximidad de un daño» y ventura como palabra que expresa que «una cosa se expone a la contingencia de que suceda un mal o un bien»". La imputación del riesgo y ventura al contratista determina, por tanto, que éste asume el daño o perjuicio que puede resultar de la ejecución del contrato, de manera que ningún derecho le asiste para exigir de la Administración contratante una compensación en caso de que el coste de la ejecución sea más elevado de lo

2 Véase J. A. Santamaría Pastor (2013), «La constante e interminable reforma de la normativa sobre contratación pública», Revista Española de Derecho Administrativo, 159, págs. 25 ss. 
previsto (por todas, STS de 27 de octubre de 2009, rec. 763/2009) ${ }^{3}$. Ahora bien, también se ha puntualizado que, como contrapartida al perjuicio, al contratista igualmente le corresponde el bien o beneficio - más allá de lo previsto y siempre por relación a la equivalencia de las prestaciones pactadas en el momento de la perfección del contrato- que pueda producirse a resultas de dicha ejecución ${ }^{4}$.

En segundo lugar, la concreción del riesgo y ventura exige tener en cuenta las condiciones económicas del contrato y, por tanto, tomar siempre como punto de comparación lo pactado en el momento de la perfección del mismo. Es la inmutabilidad resultante del contractus lex lo que lleva a que sean las condiciones pactadas lo que permite medir los resultados derivados de la ejecución, tal como viene a confirmarlo el art. 189 de la vigente LCSP.

En tercer lugar, una consecuencia importante de lo hasta este momento dicho es que al asignarse el riesgo y ventura al contratista, la Administración contratante permanece ajena al mismo, de manera que, en principio, no le alcanzan los perjuicios, ni tampoco los beneficios, que la ejecución del contrato pueda deparar. Sin embargo, conviene ya advertir que la entrada en juego del llamado principio de equilibrio económico-financiero del contrato, modulando o matizando el riesgo y ventura del contratista y haciendo partícipe a la Administración - al menos teóricamente- de las consecuencias desfavorables del riesgo, determina que en algunos casos esta asuma no solo parte de los perjuicios, sino también, en su caso, de los beneficios que la ventura pueda deparar (arts. 270.2 y 290.4 LCSP, en relación a los contratos de concesión de obras y de concesión de servicios).

En cuarto lugar, debe añadirse que el riesgo y ventura del contratista no es una singularidad de la contratación pública. También rige en la contratación civil (por ejemplo, arts. 1590 y 1593 CC). Estamos, sencillamente, ante una regla que la doctrina civilista no ha dudado calificar de justa, «al ser el riesgo de aumento de costos consustancial a la función empresarial del contratista» que, además, "puede prevenir y evitar ese perjuicio» ${ }^{5}$.

3 E. García de Enterría (1950), «Riesgo y ventura y fuerza mayor en el contrato administrativo", Revista de Administración Pública, 2, pág. 83, ya recordó lo dicho, en los mismos términos, por la STS de 18 de junio de 1947.

4 Entre otras muchas más, SSTS de 20 de julio de 2016 (rec. 339/2015), fundamento de derecho 7, o de 27 de octubre de 2009 (rec. 763/2007), fundamento de derecho 1. Por eso mismo, la STS de 16 de diciembre de 2013 (rec. 2882/2012), frente a la pretensión de la Administración de reducir el precio del contrato en la cuantía correspondiente a la rebaja del tipo del IVA, concluye que, dado que es el contratista quien asume el riesgo y ventura, "la retribución pactada entre la Administración contratante y el contratista no puede modificarse, ni al alza ni a la baja, como consecuencia de las fluctuaciones del tipo de gravamen propio de este tributo".

5 Véase L. Díez-Picazo y A. Gullón Ballesteros (1973), Instituciones de Derecho Civil, I, Madrid: Tecnos, pág. 529. En efecto, el contratista "puede prevenir y evitar ese perjuicio», dado que, según consolidado entendimiento de la Sala Primera del TS, debe considerarse 
En quinto lugar, la asignación del riesgo y ventura al contratista no viene acompañada de precisión legal alguna sobre qué tipos de riesgos engloba, por lo que, en principio, cualesquiera riesgos — todos los que se puedan producir- le son imputables. Cuestión distinta es que, en algunos contratos, determinados y específicos riesgos en ningún caso pueden llegar a materializarse. No otra cosa sucede, como es lógico, con los riesgos de demanda y de suministro en la explotación de obras y de servicios, que solo alcanzan a los contratos de concesión de obras y de servicios. Tanto es así que para tales contratos, el llamado riesgo operacional ha terminado erigiéndose ${ }^{6}$ - aunque de una manera innecesaria y hasta incorrecta en estrictos términos jurídicos- en el dato que los singulariza y diferencia de todos los demás, y, en especial, por relación al contrato de servicios en la nueva modalidad de "contratos de servicios que conlleven prestaciones directas a favor de la ciudadanía» (art. 312 LCSP).

El llamado riesgo operacional no deja de ser un específico tipo de riesgo que forma parte o se engloba en la genérica categoría del riesgo y ventura del contratista, si bien solo se puede materializar en los contratos de explotación de obras y de servicios. Cuestión distinta es que en el tradicional contrato de gestión de servicios públicos ese riesgo operacional pudiera excluirse o modularse por la vía de los pliegos de condiciones e, incluso, por el propio legislador y la jurisprudencia, en los términos que más adelante veremos. Una posibilidad que, sin embargo, queda ahora descartada por imperativo de la normativa comunitaria - y, a resultas de la misma, por la nueva LCSP de 2017_, siempre que se trate propiamente de un contrato de concesión.

Más allá de la señalada singularidad del riesgo operacional, como un riesgo que en ningún caso puede quedar excluido del riesgo y ventura del concesionario, desde una perspectiva ahora negativa la LCSP prevé algunos supuestos en los que dicho riesgo queda excepcionado. Unas excepciones que, como vamos a ver seguidamente, determinan que la amplitud del riesgo y ventura del contratista no termine de coincidir con la que en las exposiciones doctrinales - y hasta jurisprudenciales, aunque en la mayoría de los casos solo en un plano teórico o doctrinal, que no práctico- se le suele atribuir.

Queda por decir que, en todo caso, del riesgo y ventura del contratista han de quedar excluidos todos aquellos hechos que traigan causa de la acción del propio contratista o de la propia Administración contratante. Aunque la legislación contractual ha terminado por agrupar bajo el principio del equilibrio económi-

que las referidas normas civiles son, en realidad, «regla interpretativa de una voluntad tácita de las partes», o, en otros términos, no son «normas de derecho necesario» o «normas prohibitivas de pactos en contrario a ellas, sino meramente dispositivas" (entre otras muchas más, SSTS Sala Primera, de 23 de junio de 1964, de 18 de diciembre de 1970, de 14 de abril de 1972, de 25 de junio de 1979, de 13 de junio de 1997, de 22 de diciembre de 1997, de 21 de junio de 2000, etc.).

6 Véanse los arts. 14.4, 15.2, 270.2, párrafo 3º, y 290.4, párrafo 3º, LCSP. 
co-financiero de los contratos - y, en particular, de los contratos de concesiónla regulación de los efectos de la modificación de los contratos por decisión unilateral de la Administración [arts. 270.2.a) y 290.4.a), LCSP], lo cierto es que esos efectos son consustanciales a todo contrato, al estar este presidido por la inmutabilidad del pacto y el mantenimiento de la equivalencia de las respectivas prestaciones acordadas.

\section{EXCEPCIONES A LA REGLA DEL RIESGO Y VENTURA DEL CONTRATISTA}

Visto el significado general de la regla del riesgo y ventura del contratista, es el momento de contrastar con la LCSP vigente - y aún con las precedentes LCE de 1965, LCAP de 1995, y LCSP de 2007, además del Reglamento de Servicios de las Corporaciones Locales de 1955 (RSCL) - las excepciones a las que, según la doctrina y la jurisprudencia, se enfrenta dicha regla general. Lo haré, no obstante, en un orden parcialmente distinto al que suelen enumerarse tales excepciones, comenzando con el estudio de la fuerza mayor para continuar con el llamado factum principis, el riesgo imprevisible y el ius variandi.

\section{FUERZA MAYOR}

Establece el art. 239 LCSP que cuando los daños y perjuicios del contratista traigan causa de la concurrencia de un supuesto de «fuerza mayor», la Administración contratante deberá «indemnizarlos», tipificando seguidamente los supuestos calificables como «fuerza mayor». No obstante, esta excepción queda ceñida al contrato de obras, dada la remisión del art. 197 al 239 LCSP y, asimismo, a los contratos de concesión de obras - en relación con la ejecución y la explotación de las obras (arts. 254.2 y 270.2 LCSP) — y de concesión de servicios (art. 290.4 LCSP).

Esta regulación resulta desigual, sin que exista razón para que así lo sea. De una parte, la excepción de la fuerza mayor no se extiende a todos los contratos. Y, de otra, con arreglo a la literalidad de la LCSP, en el contrato de obras el perjuicio - la mayor onerosidad - debido a fuerza mayor ha de ser indemnizado por la Administración sin que se condicione a su gravedad o trascendencia económica (art. 239.1 LCSP), mientras que, respecto de los contratos de concesión de obras y de servicios, para que haya lugar al restablecimiento del equilibrio económico-financiero será preciso que la fuerza mayor haya ocasionado «de forma directa la ruptura sustancial de la economía de la concesión» (arts. 270.2, párrafo $2^{\circ}$, y 290.4 , párrafo $2^{\circ}$ ). Convendría, pues, que se corrigiese la regulación vigente a fin de superar este tratamiento fragmentario y dispar de la fuerza mayor como causa de excepción o quiebra de la regla del riesgo y ventura del contratista.

Con lo dicho no se agotan las consecuencias vinculadas a la concurrencia de fuerza mayor en la ejecución de los contratos. Y es que la fuerza mayor también se 
tiene en cuenta por la ley a la hora de regular las causas que posibilitan la modificación de los mismos, así como en la enumeración de las causas determinantes de su resolución [arts. 205.2.b) y 211.1.g), LCSP, sin perjuicio de lo específicamente dispuesto por el art. 254.2 para el contrato de concesión de obras].

En todo caso, hay que añadir que no basta con que concurra un hecho calificable como fuerza mayor para que cualquiera de las consecuencias señaladas tengan que reconocerse. El art. 239 LCSP puntualiza que el derecho del contratista a la indemnización por los dańos y perjuicios se condiciona a que no haya existido «actuación imprudente» a él imputable, y aunque pueda parecer contradictorio que se vincule fuerza mayor e imprudencia ${ }^{7}$, es indudable que la diligencia del contratista puede ser decisiva a la hora de evitar o atemperar las consecuencias resultantes del hecho imprevisible o inevitable. El hecho será inevitable, pero las consecuencias del mismo — el daño y perjuicio— no tienen por qué serlo.

Por otra parte, ante la duda de si la enumeración legal de los supuestos calificables como fuerza mayor es exhaustiva o si, por el contrario, permite la ampliación a supuestos similares o equiparables a los previstos, esta posibilidad no parece que sea descartable a la vista de la posición mantenida por el TS en algunas ocasiones, como es el caso de la STS de 28 de noviembre de 2017 (rec. 2615/2015), fundamento de derecho 3, ya que, en línea de continuidad con lo dicho en la STS de 6 de abril de 2017 (rec. 453/2016), si bien rechaza que en el caso concreto planteado hubiera lugar a declarar la existencia de fuerza mayor, lo relevante es que no lo hace porque el hecho no fuera reconducible a alguno de los concretos supuestos legales —que evidentemente no lo era, al alegarse como tal la crisis económica y las exigencias dimanantes de la necesaria estabilidad presupuestaria y sostenibilidad financiera-, sino sencillamente porque no se trataba de un hecho imprevisible o irresistible ${ }^{8}$.

Ahora bien, no es aceptable que la calificación de fuerza mayor pueda extenderse a cualesquiera hechos por ser sin más imprevisibles o inevitables, ya que es lógico que la naturaleza o las características de los hechos tengan que ser, al menos, similares o análogas a las de los supuestos expresamente previstos por la Ley. La fuerza mayor no es sin más equivalente al riesgo imprevisible y de ahí que, por reconducir ahora la cuestión a las circunstancias actuales derivadas de la pande-

7 Lo señalan J. L. Villar Palasí y J. L. Villar Ezcurra (2004), «Fuerza mayor», en R. Gómez-Ferrer Morant (dir.), Comentario a la Ley de Contratos de las Administraciones Públicas, 2a ed., Madrid: Civitas, pág. 870.

8 En realidad, la jurisprudencia, desde antiguo, al considerar los supuestos de fuerza mayor siempre ha resaltado la nota de su imprevisibilidad, por lo que le ha bastado constatar que el hecho o circunstancia era previsible en el momento de contratar para descartar que la materialización del riesgo sea calificable como un supuesto de fuerza mayor. Así, entre otras, SSTS de 2 de enero de 1980 (ar. 148), de 19 de octubre de 1983 (ar. 5207), y de 29 de enero de 1982 (ar. 235) [todas estas sentencias y algunas más recogidas en J. A. Santamaría Pastor y L. Parejo Alfonso (1989), Derecho Administrativo. La jurisprudencia del Tribunal Supremo, Madrid: Centro de Estudios Ramón Areces, pág. 425]. 
mia que hemos vivido y aún padecemos, más que tratar de forzar la interpretación del art. 239.2 LCSP para limitar las consecuencias del riesgo y ventura por razón de fuerza mayor, resultaba más lógico que el legislador interviniese adoptando las oportunas medidas, tal como, por lo demás, no ha dejado de hacer? .

También se ha criticado doctrinalmente que la jurisprudencia haga recaer en el contratista la carga de la prueba de que, ante el supuesto de fuerza mayor, no ha actuado de manera imprudente o carente de la debida diligencia. Sin embargo, no puede decirse, al menos con carácter general, que así se exija. El contratista deberá probar, ciertamente, que el hecho es constitutivo de un supuesto calificable como fuerza mayor, así como los correspondientes daños. Pero es la Administración quien, en su caso, habrá de probar que el contratista no actuó con diligencia suficiente en orden a prevenir o evitar las consecuencias resultantes del mismo ${ }^{10}$.

Quedan por ver las consecuencias indemnizatorias de la fuerza mayor y las medidas compensatorias que se prevén.

En cuanto a lo primero, la jurisprudencia ha sido cambiante ${ }^{11}$, pero las SSTS de 10 de marzo y de 24 de abril de 2008 (rec. 398/2006 y 5816/2005, respectivamente), fundamento de derecho 3 , han aclarado definitivamente la cuestión, optando por una interpretación amplia y extensiva de los daños y perjuicios resarcibles. Por ello pueden tomarse en cuentan tanto el dańo emergente como el lucro cesante y, por ende, "comprende tanto los perjuicios materiales que abarcan las unidades de obras ejecutadas pero destruidas, las pérdidas de instalaciones, materiales y equipos necesarios para las obras, el deterioro de la maquinaria, como los perjuicios derivados por su paralización y el coste financiero ya que todos esos conceptos se engloban en el marco legal aplicable».

Y en cuanto a la compensación debida a fuerza mayor en los contratos de concesión de obras y de concesión de servicios, los arts. 270.3 y 290.5 LCSP establecen las diversas medidas que a tal efecto podrán adoptarse, si bien, a pesar de que no se prevé expresamente que la compensación pueda consistir en una indemnización o abono de la correspondiente suma dineraria en la que se hayan cifrado los daños y perjuicios, de la mera falta de mención no parece que pueda concluirse que dicha medida compensatoria queda por completo desechada ${ }^{12}$.

9 Véase el art. 34.4 del Real Decreto Ley 8/2020, de 17 de marzo, de medidas urgentes extraordinarias para hacer frente al impacto económico y social de la COVID-19.

10 No otra es, por ejemplo, la posición que se mantiene en la STS de 17 de julio de 2018 (rec. 638/2017).

11 Por ejemplo, la STS de 5 de febrero de 1986 (ar. 454), dentro de los conceptos resarcibles por concurrir fuerza mayor, reconoció la extensión de la indemnización a la maquinaria adscrita a la obra, mientras que la STS de 19 de mayo de 1987 (ar. 4511), excluyó de la indemnización los dańos en elementos que no afectan directamente a la obra, como pueden ser los derivados de un corte de energía eléctrica, ya que el mismo solo implica demora en la ejecución.

12 Véase STS 8 de junio de 2016 (rec. 1208/2015), fundamento de derecho 6. 


\section{2. «ACTUACIONES» DE LA ADMINISTRACIÓN CONTRATANTE QUE ALTERAN LA EQUIVALENCIA DE LAS PRESTACIONES PACTADAS. EL LIMITADO ALCANCE DEL FACTUM PRINCIPIS}

Junto a la fuerza mayor, la LCSP prevé, aunque solo para los contratos de concesión de obras y de concesión de servicios, una excepción más al riesgo y ventura del contratista en la ejecución del contrato. Los arts. 270.2.b) y 290.4.b) LCSP, con la misma redacción, disponen lo siguiente:

«Se deberá restablecer el equilibrio económico del contrato, en beneficio de la parte que corresponda, en los siguientes supuestos: [...] Cuando actuaciones de la Administración Pública concedente, por su carácter obligatorio para el concesionario determinaran de forma directa la ruptura sustancial de la economía del contrato».

Este nuevo supuesto de excepción del riesgo y ventura del contratista parece acoger lo que doctrinalmente se califica como factum principis. No obstante, habrá que convenir que, en todo caso, lo hace parcialmente, al menos si se admite que conceptualmente la decisión del poder público que incide en el contrato, alterando sus presupuestos económicos, puede proceder tanto de la Administración contratante - aunque, por lo que más adelante se dirá, en el ejercicio de poderes distintos a los contractuales-, como de cualquier otra Administración, y que, incluso, hasta podría englobar decisiones del propio poder legislativo riesgo regulatorio_-, a pesar de que el Consejo de Estado expresamente lo haya descartado.

A este respecto, no deja de ser significativo el hecho de que, a diferencia de la LCSP de 2007 —que, al igual que la inicial Ley 13/2003, de 23 de mayo, se refería sin más a «actuaciones de la Administración»-, la nueva regulación expresamente cińa el supuesto a que se trate de «actuaciones de la Administración concedente». Una restricción que, de todas formas, incluso bajo la vigencia de la LCSP de 2007 y el TRLCSP de 2011, la jurisprudencia no ha dejado de avalar expresamente $^{13}$, si bien no siempre lo haya hecho con argumentos convincentes ${ }^{14}$.

13 Véase STS de 16 de mayo de 2011 (rec. 566/2008), a la que más adelante me referiré. Asimismo, STS de 12 de mayo de 2008 (rec. 478/2007), fundamento de derecho 4, con ocasión de obras realizadas por una concesionaria de autopista no ordenadas por la Administración contratante, sino por sugerencia de otras Administraciones, y que se pretendía fueran indemnizadas.

14 Es el caso, por ejemplo, de la STS de 19 de diciembre de 2019 (rec. 2390/2016), fundamento de derecho 8, al afirmar que «es evidente que solo las actuaciones de la Administración contratante - $\mathrm{y}$ no las de otra- son las que pueden determinar la ruptura sustancial de la economía de la concesión». Sin embargo, con ello se viene a dejar sin contenido a un supuesto de restablecimiento del equilibrio económico-financiero del contrato que, añadido al de la alteración del equilibrio por el ejercicio del ius variandi y la fuerza mayor, es, por ello mismo, 
En cualquier caso, el factum principis como causa determinante del reequilibrio del contrato de concesión ha de incidir en el mismo provocando «la ruptura sustancial de su economía", con lo que se marca una diferencia más con el restablecimiento del equilibrio debido al ejercicio del ius variandi de la Administración contratante, que únicamente queda excluido cuando sus consecuencias "carezcan de trascendencia económica» (arts. 270.5 y 290.3 LCSP). Aunque nada se precisa acerca de cuándo puede considerarse que se materializa una ruptura sustancial de la economía del contrato, es indudable que se ha de tratar de un grave desequilibrio económico, consistente en pérdidas reales y efectivas que pongan en riesgo la continuidad de la prestación del servicio, no siendo suficiente con que la «actuación» administrativa tenga alguna trascendencia económica y haga, por tanto, más onerosa la ejecución del contrato.

Por lo demás, la recomposición del equilibrio se llevará a cabo mediante la adopción de las medidas previstas por la LCSP que resulten más adecuadas para posibilitar que el contratista mantenga las prestaciones comprometidas. Y esas medidas, de acuerdo con lo dispuesto por los arts. 270.3 y 290.5, son las mismas que se prevén para los supuestos de fuerza mayor, de manera que puede quedar justificada tanto una reducción como una elevación de la cuantía de la tarifa, o una reducción de la retribución a abonar por la Administración al concesionario, o, incluso, una reducción o, limitadamente, una ampliación del plazo concesional. Aspectos todos estos que podrán ser precisados en los correspondientes pliegos de condiciones.

Debe añadirse que las «actuaciones» de cualquier otra Administración ajena a la relación contractual que tengan incidencia en la ejecución del contrato no dan lugar al restablecimiento del equilibrio económico de la concesión, aunque sí se toman en consideración al efecto de posibilitar que el contratista desista del contrato cuando consistan en »la aprobación de una disposición general» y determinen que el cumplimiento del contrato devenga "extraordinariamente oneroso» (art. 270.4, párrafo $1^{\circ}$, para la concesión de obras, y 290.6, párrafo $1^{\circ}$, para la concesión de servicios). Y, de manera complementaria, los párrafos $2^{\circ}$ de los referidos artículos, a diferencia de lo que sucede con el requisito de la «ruptura sustancial de la economía del contrato" al que se condiciona el reequilibrio económico del contrato, concretan qué se entiende por cumplimiento «extraordinariamente oneroso» ${ }^{15}$.

conceptualmente distinto y diferenciable, con independencia de la amplitud o extensión que el legislador decida darle englobando a «actuaciones» de cualesquiera Administraciones o, por el contrario, exclusivamente a las de la propia Administración contratante o «concedente», en el ejercicio — lógicamente- de poderes distintos a los contractuales.

15 En concreto, «cuando la incidencia de las disposiciones de las Administraciones [...] supongan un incremento neto actualizado de los costes de, al menos, el 5 por ciento neto de la cifra de negocios de la concesión por el periodo que reste hasta la conclusión del 
Por consiguiente, lo relevante termina siendo a quién es imputable la actuación. Sólo si lo es a la Administración contratante podrá surgir el derecho del contratista al reequilibrio de la economía del contrato, aunque no podrá desistir del mismo. Por el contrario, si lo es a otra Administración, y siempre que se trate de una actuación consistente en la aprobación de una disposición general, únicamente cabrá la posibilidad de que el concesionario desista del contrato. Y, asimismo, en los dos supuestos la incidencia de la «actuación» en la economía del contrato ha de ir más allá de provocar una mayor onerosidad, aunque, como ya hemos dicho, mientras que la ley precisa cuándo se ha de considerar que se produce una «extraordinaria onerosidad» en el cumplimiento del contrato, por el contrario guarda absoluto silencio acerca de qué se debe entender por «ruptura sustancial de la economía» de la concesión.

Hay que señalar, por otra parte, que los arts. 270.4, párrafo $3^{\circ}$, y 290.6, párrafo $3^{\circ}$, LCSP, establecen que el desistimiento no conllevará indemnización alguna. Pero no deja de plantearse la duda de si con ello queda excluida la compensación prevista en los arts. 280.1, párrafo $2^{\circ}$ - para la resolución del contrato de concesión de obras - y 295.1, párrafo $2^{\circ}$ — respecto de la resolución del contrato de concesión de servicios-, ambos LCSP, siempre que la resolución lo sea por alguna de las «causas no imputables a la Administración» previstas en las letras a, b) y f) del art. 211, y, además, específicamente para el contrato de concesión de obras, en las letras a) y f) del art. 279, y para el contrato de concesión de servicios, en las letras a) y f) del art. 294.

Pues bien, dado que el desistimiento determina la extinción del contrato concesional - aun cuando no figure expresamente entre las causas generales y específicas de resolución-, la duda debe resolverse en el sentido de reconocer ese derecho a la compensación, ya que este responde a una lógica que es en parte distinta a la que preside la indemnización de daños y perjuicios, de acuerdo con el criterio de imputación de la causa de resolución a una u otra de las partes contractuales ${ }^{16}$. Y no otra cosa sucede con el desistimiento, pues este no se produce por causa imputable al concesionario, dado que el mismo se debe a la extraor-

16 La compensación, incluso cuando era totalmente independiente de que concurrieran unas u otras causas de resolución, tal como se ha señalado en la doctrina [véase, por ejemplo, R. Bocanegra Sierra (2016), «La renuncia a las concesiones de obra como solución equilibrada en los supuestos de ruptura del equilibrio económico del contrato", en Memorial para la reforma del Estado. Estudios en homenaje al profesor Santiago Muñoz Machado, t. III, pág. 2574, Madrid: CEPyC], no debe considerarse «en principio, un $<<$ regalo $>>$ del legislador, un enriquecimiento injusto del concesionario [...], de modo que una resolución sin abono del importe de la obra ocasionaría, en estricta dogmática de Derecho de contratos, un desequilibrio patrimonial e incluso - aunque es más discutible - un enriquecimiento injusto de la Administración [...]». En todo caso, la cuantía de la compensación por la (mal) llamada responsabilidad patrimonial de la Administración (RPA) podía quedar descontada, a su vez, por la resultante de los dańos y perjuicios resultantes de la resolución por causa imputable al concesionario, a no ser, claro, que aquella se hubiera pignorado a favor de 
dinaria onerosidad del contrato que provoca «la aprobación de una disposición general por una Administración distinta de la concedente» o, como más adelante veremos, por razón de la obligación — legal o contractual- del concesionario de incorporar los avances técnicos que, de acuerdo con el estado de la técnica, mejoren notoriamente la explotación y gestión de la obra o servicio ${ }^{17}$.

No cabe descartar, en fin, que cualesquiera actuaciones de la Administración contratante, así como las de otras distintas, puedan ir mucho más allá de provocar una extraordinaria onerosidad en el cumplimiento del contrato, haciendo sin más «imposible» la explotación de las obras o la explotación del servicio, en cuyo caso los contratos de concesión de obras y de servicios, respectivamente, quedarán resueltos [arts. 279.e) y 294.e) LCSP]. Una resolución que con arreglo a lo dispuesto en los arts. 280.3 y 295.4 LCSP, determina que la Administración tenga que abonar «en todo caso al concesionario el importe de las inversiones realizadas por razón de la expropiación de terrenos, ejecución de obras de construcción y adquisición de bienes que sean necesarios para la explotación de la obra objeto de la concesión, atendiendo a su grado de amortización (arts. 280.1 y 295.1 LCSP), y, asimismo, la correspondiente indemnización "por los daños y perjuicios que se le irroguen», previendo, al respecto, que para la fijación de la cuantía indemnizatoria habrá que estar a los criterios del art. 280.3, párrafo 2, LCSP y, por tanto, a los beneficios futuros que se pierden y a la pérdida del valor de las obras e instalaciones que no hayan de ser entregadas a la Administración, considerando su grado de amortización.

Sobre esta causa de resolución se debe precisar que, en el caso del contrato de concesión de obras, la misma se refiere a «acuerdos adoptados por la Administración concedente con posterioridad al contrato» [art. 279.e)], mientras que en el contrato de concesión de servicios se trata de "acuerdos adoptados por la Administración con posterioridad al contrato» [art. 294.e)]. De este modo, la desigual redacción - que no termina de comprenderse- provoca una inseguridad indeseable, dadas las consecuencias que para la resolución y, de manera añadida, sus efectos tiene el hecho de que la imposibilidad de la explotación se deba a acuerdos de la Administración contratante o también a acuerdos de otra Administración. Aunque parece más lógico que los acuerdos — por lo demás, no necesariamente de naturaleza normativa, a diferencia del supuesto que habilita el desistimiento, que expresamente se circunscribe «a la aprobación de una disposición general por una Administración distinta de la concedente»— puedan proceder de cualquier Administración, he aquí, en todo caso, una nueva deficiencia de la regulación que mucho convendría corregir.

terceros: véase, a este respecto, M. Fuertes (2018), Las desventuras del dinero público. Elegía al principio de «riesgo y ventura», Madrid: Marcial Pons, págs. 105 ss.

17 También se manifiesta favorable a reconocer el derecho a la referida compensación R. Sahún Pacheco (2019: 266). 
Por lo demás, la aplicación judicial de la causa de resolución del contrato de concesión por imposibilidad de explotación del servicio resulta desigual a la vista de la STS de 13 de mayo de 2015 (rec. 1073/2014), de una parte, y las SSTS de 26 de abril de 2017 (rec. 2688/2016) y de 18 de julio de 2018 (rec. 2692/2016), de otra, ya que, a pesar de plantearse sustancialmente la misma cuestión y ser también similares los hechos - concretamente, la procedencia o no de la resolución de unos contratos de gestión del servicio público que prestaban en el término municipal de Bilbao los «ascensores de Arangoiti», en un caso, y los «ascensores A Begoña», en el otro—, mientras que la STS de 13 de mayo de 2015 mantendría que lo que caracteriza a esta causa de resolución es que «se produzcan efectivas actuaciones formales de la Administración que determinen, en términos jurídicos objetivos y unívocos, la privación del objeto y del contenido de la prestación del servicio, y lo imposibiliten en un sentido contractual lato, y no solo en el ámbito de la percepción económica y material que el concesionario albergue sobre su capacidad de prestar el servicio en las condiciones en que se le retribuye», por lo que concluyó estimando improcedente la pretendida resolución, las posteriores SSTS de 26 de abril de 2017 y de 18 de julio de 2018 consideraron, por el contrario, que había lugar a la resolución — caducidad- de la concesión, ya que, en cierto modo, la imposibilidad de continuar la explotación se debió a la «insuficiente» actuación de la Administración concedente en orden a mantener el equilibrio económico-financiero de la concesión, al no haber ejercido ante una alteración imprevista y grave de la economía del contrato, dado el número decreciente de usuarios e ingresos y la insuficiencia de las tarifas para cubrir los gastos ordinarios de la explotación, "[...] sus facultades-deberes, no decimos ya prerrogativas, para corregir aquel desequilibrio».

Queda por ver la posición de la jurisprudencia respecto de este supuesto de excepción del riesgo y ventura del contratista ${ }^{18}$.

Puede comenzarse por recordar que la STS de 21 de junio de 2005 (rec. 1772/2002) consideró que no procedía la solicitud de reequilibrio de una concesión de construcción y gestión de un aparcamiento subterráneo por razón de

18 De interés son los supuestos históricos que comenta G. Ariño Ortiz (1968: 257), dada su similitud con asuntos planteados en la actualidad. Es el caso de la supresión de un arbitrio "por orden superior» que, al afectar económicamente al contrato de arrendamiento de arbitrios celebrado por un Ayuntamiento, determina que éste quede obligado a abonar al contratista la cantidad que como consecuencia de dicha supresión dejó de percibir. O el de la disminución de los productos de un portazgo (vinculado a la construcción de un puente) como consecuencia de la apertura de una línea férrea. También nos traen a la actualidad la STS de 12 de mayo de 1875, con ocasión de la indemnización reclamada por los perjuicios sufridos en un arriendo de arbitrios debidos al cordón sanitario acordada en algunos pueblos como consecuencia de la fiebre amarilla, y la STS de 7 de marzo de 1895, con ocasión del contrato de obras de ampliación del puerto de Málaga, cuya realización se había visto encarecida considerablemente al haber sido gravada, en los nuevos aranceles, la cal hidráulica que se debería emplear en la construcción. 
que el Ayuntamiento modificara el régimen de circulación y aparcamiento en superficie en las inmediaciones del estacionamiento, afectando así al régimen económico del contrato, si bien ello se debió a que en el pliego se había estipulado expresamente que el Ayuntamiento podía adoptar cualesquiera modificaciones de dicho régimen libremente, sin que el concesionario tuviera derecho a reclamación ni compensación alguna.

Por el contrario, con ocasión de la reclamación del restablecimiento del equilibrio económico por la concesionaria de un servicio de aparcamientos en la vía pública con control de horario, basando la misma en la disminución de ingresos debida a la inaplicación por el Ayuntamiento de la Ordenanza sobre Regulación del Tráfico y la falta de actuación de la grúa municipal, las SSTS de 16 de junio de 2004 (rec. 4289/1999) y de 5 de abril de 2005 (rec. 7428/2001) confirman las sentencias de instancia que estimaron probada la inoperancia del sistema de control de horario establecido por el Ayuntamiento, ya que no se prestó apoyo policial a las denuncias, no se impusieron en número necesario sanciones a los conductores que infringieron las normas sobre aparcamiento, no se procedió debidamente a la retirada de vehículos por la grúa, ni, en fin, se procedió a la revisión de los precios fijados después de transcurrido el primer año del otorgamiento de la concesión, todo lo cual determinó el fracaso económico de la concesión achacable a la conducta municipal, por lo que se declara el derecho al restablecimiento del equilibrio.

Asimismo, la STS de 7 de marzo de 2018 (rec. 2799/2015), ante la denegación del «rescate» anticipado y de la indemnización que solicitara el concesionario de la construcción y explotación de una estación de suministro de combustible en el puerto de Benicarló, y ello como consecuencia de que la Administración que otorgó la concesión posteriormente autorizó a la Cofradía de Pescadores para surtirse de combustible mediante cisternas, lo que provocó que se "desplomaran» las ventas de la concesionaria, afirma que el riesgo y ventura del concesionario tiene excepciones y que, justamente en el caso planteado, «estamos ante una de las excepciones que prevé nuestro ordenamiento jurídico, respecto de esa aleatoriedad propia de los contratos administrativos, y que acarrea el reequilibrio de la ecuación financiera cuando el deterioro se produce por causas imputables a la Administración ("factum principis»), ex artículo 248.2 de TRLCAP, que introduce la Ley 13/2003, de 23 de mayo, reguladora del contrato de concesión de obras públicas» (fundamento de derecho 5). De este modo, se desestima la casación planteada y queda confirmada la sentencia de instancia que anuló la denegación y reconoció el derecho al «rescate» solicitado ${ }^{19}$.

19 No obstante, obsérvese que el factum principis no lleva al restablecimiento del equilibrio económico-financiero del concesionario, sino, sencillamente, a admitir la procedencia del rescate de la concesión por la Administración, dado que, al parecer, el «desplome» de las ventas de carburante hacía inviable la explotación económica del servicio. Sin embargo, no parece que, en estrictos términos, fuera procedente reconocer el derecho al rescate solici- 
En alguna ocasión, aunque sin ninguna cobertura legal, ni contractual, la jurisprudencia ha apelado al factum principis para compensar al contratista por la alteración de la economía del contrato debida a incrementos de los precios de los materiales necesarios para el cumplimiento de la prestación [SSTS de 20 de noviembre de 1985 (ar. 5566) ${ }^{20}$ y de 2 de diciembre de 1985 (ar. 6511)].

También en algunas de las sentencias relativas a la elevación de los precios de los «ligantes asfálticos», el reconocimiento del derecho indemnizatorio del contratista se vinculó al hecho de la intervención de la Administración sobre los precios del petróleo, en un momento, por tanto, en el que no estaban liberalizados [STS de 27 de octubre de 2009 (rec. 763/2007) y algunas otras más ${ }^{21}$ ].

En este recorrido jurisprudencial debe citarse, igualmente, la STS de 9 de mayo de 2014 (rec. 1457/2013), que ante la solicitud de la empresa concesionaria de unos centros residenciales públicos de atención a personas mayores de una indemnización por la concurrencia de determinadas circunstancias que consideraba habían alterado el equilibrio económico-financiero de la concesión - retrasos en la ejecución de las obras de construcción de las residencias y centros de día que tuvieron su causa en el hecho de que la Administración no proporcionó las parcelas en donde tenían necesariamente que edificarse-, y todo ello al amparo de lo dispuesto por el apdo. 2.b) del art. 248 TRLCAP, en el fundamento de derecho 6 concluye que:

[...] los alegatos efectuados en la demanda para apoyar el restablecimiento económico del contrato no son reconducibles a ninguno de los supuestos que se enumeran en el apartado 2 de dicho artículo 248. Así ha de ser considerado desde el momento en que esos alegatos no exteriorizan unas decisiones de la Administración modificativas de las condiciones de explotación de la obra; ni una causa de fuerza mayor; tampoco una actuación administrativa técnicamente calificable de factum principis, al no tratarse de decisiones generales sobre materias ajenas al contrato pero con incidencia sobre el mismo; y, por último, tampoco justifican una singular previsión del contrato sobre su revisión.

tado. Más correcto habría sido declarar, en su caso, que concurría causa de resolución del contrato por imposibilidad de la explotación del servicio debido al acuerdo de la Administración concedente.

20 Fue comentada por T. Quintana López (1986), «El anacronismo del factum principis en la legislación de contratos», Revista Española de Derecho Administrativo, 50, págs. 269 ss.

21 A todas esas sentencias relativas a la misma problemática —incidencia de la elevación del precio del producto necesario para la prestación a la que está obligado el contratista- me referiré más adelante, al tratar del riesgo imprevisible, ya que ponen de manifiesto como la jurisprudencia, a partir de las SSTS de 18 de abril de 2008 (rec. 5033/2006), de 25 de abril de 2008 (rec. 5038/2006), de 6 de mayo de 2008 (rec. 5111/2006) y la ya citada de 27 de octubre de 2009 (rec. 763/2007), etc., corrigió radicalmente el criterio que con anterioridad había venido manteniendo. Pero es justamente a propósito de ese cambio cuando se argumenta que, en realidad, los supuestos no son del todo equiparables, ya que los precios habían dejado de estar intervenidos. 
Por tanto, la pretensión de la concesionaria debió haber consistido, en todo caso, en «solicitar la correspondiente indemnización por incumplimiento contractual», y no, tal como hizo, en "pretender el restablecimiento del equilibrio del contrato de concesión».

Por el contrario, la STS de 6 de junio de 2016 (rec. 1610/2015) estimó que los perjuicios en la ejecución del contrato debidos al retraso en el otorgamiento de las autorizaciones y licencias que debía conceder la propia Administración retraso en las autorizaciones de los préstamos y retrasos en las autorizaciones de los enlaces, con repercusión en el «incremento de indirectos» y sobrecostes por aceleración-, no se debieron "a un hecho previsible» - lo fueron, por tanto, a un hecho imprevisible- , por lo que deben quedar al margen del riesgo y ventura del contratista y debe reconocérsele el derecho a ser compensado.

Por último, la Sala Tercera del TS ha conocido de diversos recursos de casación en los que la cuestión suscitada ha sido la de si los concesionarios de autopistas tienen derecho al restablecimiento del equilibrio económico de la concesión como consecuencia de decisiones de la propia Administración concedente —aunque, en otros casos, de una Administración distinta- en orden a mejorar, ampliar, desdoblar, etc., las carreteras existentes en el área de influencia de las mismas, lo que lógicamente provoca un descenso del número de usuarios de la autopista con la consiguiente pérdida de ingresos por peajes.

Pues bien, sin que ahora haya lugar a descender a las particularidades de cada caso, puede decirse que, con carácter general, se ha rechazado el reconocimiento del pretendido derecho al restablecimiento del equilibrio económico-financiero de la concesión. Pero lo llamativo es que esas denegaciones lo han sido por considerar que la actuación administrativa —el factum principis producidono podía considerarse «imprevisible» y que, por tanto, sus consecuencias tenían que ser soportadas por el riesgo y ventura de los concesionarios ${ }^{22}$. Sin embargo, con arreglo a esta interpretación, el factum principis queda desplazado por el riesgo imprevisible ${ }^{23}$ - es decir, queda prácticamente vaciado de contenido y efi-

22 Véase STS de 16 de mayo de 2011 (rec. 566/2008), a la que han seguido las de 20 de junio de 2011 (rec. 62/2009), 19 de diciembre de 2011 (rec. 159/2010), 4 de febrero de 2014 (rec. 486/2011), 28 de enero de 2015 (rec. 449/2012), 20 de abril de 2015 (rec. 54/2013), STS de 17 de noviembre de 2015 (rec. 2969/2014), 12 de mayo de 2016 (rec. 451/2012), 13 de junio de 2017 (rec. 2266/2015), 17 de octubre de 2017 (rec. 446/2012), 19 de febrero de 2018 (rec. 3310/2015), y la más reciente de 22 de mayo de 2019 (rec. 904/2015). En todo caso, la vinculación del factum principis a la nota de la imprevisibilidad es un requisito que la jurisprudencia viene exigiendo de manera reiterada [entre otras muchas más, SSTS de 30 de septiembre de 1982 (ar. 4919), con ocasión de un supuesto similar a los expuestos (puesta en funcionamiento de una línea de ferrocarril que redujo el tráfico de la carretera afectada)], y de 29 de enero de 1982 (ar. 235), respecto de los perjuicios sufridos por un contratista de suministros de material electrónico a TVE como consecuencia de la devaluación de la moneda acordada por el Consejo de Ministros. Ahora bien, lo que sucede es que en la apreciación de la existencia de un 
cacia $^{24}$ —, sin perjuicio, además, de que, al reconducirlo al ámbito de la previsibilidad de la actuación administrativa, se presupone que el riesgo imprevisible acampa fuera del riesgo y ventura del contratista, lo que, como más adelante veremos, no es así, o al menos no lo es en la formulación de la LCSP.

Por otro lado, la determinación del carácter imprevisible o no del hecho se mueve en tan amplio margen de apreciación que no cabe descartar que ante hechos similares las respuestas lleguen a ser opuestas. La misma STS de 16 de mayo de 2011 (rec. 566/2008) que se acaba de citar, junto a la cuestión de la incidencia del desdoblamiento de la carretera en el flujo de tráfico de la autopista, también examina si procedería restablecer el equilibrio de la concesión como consecuencia de no haberse construido la autopista Toledo-Ciudad Real-Córdoba prevista en el Plan de Infraestructuras de Transporte 2000-2007, llegando a la conclusión de que «el proyecto del que hablamos era, en el momento de presentación de las ofertas para la adjudicación de la AP-41 algo más que un evento hipotético y futuro [...] y que su ausencia altera el equilibrio económico y financiero de la concesión por lo que procede su restablecimiento». Por el contrario, la posterior STS de 12 de mayo de 2016 (rec. 451/2012), en fundamento de derecho 4, respecto de la procedencia de compensar a la concesionaria recurrente por el descenso de tráfico derivado de la no construcción de una nueva infraestructura que conectaría con la autopista de peaje que gestionaba, soslaya adentrarse en la calificación del hecho desde la perspectiva de su previsibilidad o no y resuelve la cuestión dando implícitamente por supuesto que ninguna confianza legítima podía fundar su pretensión. Y el mismo criterio se ha mantenido en la más reciente STS de 19 de diciembre de 2019 (rec. cas. 2390/2016), fundamento de derecho 5, al afirmar que «que la posibilidad de no llevarse a cabo la construcción de los tramos del Corredor Pirenaico, situados fuera de Navarra, y correspondientes al Ministerio de Fomento, «no es una circunstancia imprevisible y sobrevenida en la formalización del contrato de concesión con el Gobierno de Navarra»".

supuesto de factum principis no siempre se tiene en cuenta si la actuación era o no previsible: recuérdese, por ejemplo, como la antes referida STS de 7 de marzo de 2018 resuelve la cuestión.

24 Véase el comentario a la STS de 16 de mayo de 2011 de A. B. Casares Marcos (2012) «Límites al riesgo y ventura del concesionario de obras públicas; restablecimiento del equilibrio económico-financiero de la concesión de la autopista AP-41 Madrid-Toledo (Sentencia del Tribunal Supremo de 16 de mayo de 2011, Sala 3a ${ }^{a}$, sección 7o, recurso contencioso núm. 566/2008)», en Administración y Justicia. Un análisis jurisprudencial. Liber amicorum Tomás-Ramón Fernández, I, Madrid: Civitas, págs. 930 y 932. Asimismo, las puntualizaciones de E. Arimany Lamoglia (2011), «El equilibrio económico financiero de la concesión de obra pública: a propósito de la sentencia del Tribunal Supremo, Autopista Madrid-Toledo. AP-41», Actualidad Jurídica Uría Menéndez, núm. extra 1, págs. 93 ss., y de M. Carlón Ruiz (2018), «El principio de mantenimiento del equilibrio económico de las concesiones: estado de la cuestión en la nueva Ley de 9/2017», en Estudios en homenaje al profesor A. Menéndez Rexach, II, Madrid: Aranzadi Thomson Reuters, págs. 851 ss. 
Así pues, la doctrina jurisprudencial que reconduce el factum principis al riesgo imprevisible a fin de negar el restablecimiento del equilibrio económico-financiero de las concesiones de autopistas afectadas en los tráficos previstos por la ulterior construcción o mejora de otras infraestructuras viarias - ya que considera que se trata de un riesgo previsible- está plenamente consolidada. También por lo que respecta a las frustradas expectativas de que esas infraestructuras vayan a realizarse. Aunque no es menos cierto que en algunas ocasiones se ha resuelto de manera más expeditiva, simplemente orillando esa doctrina ${ }^{25}$.

Hasta aquí este recorrido por los pronunciamientos más relevantes de la Sala Tercera del TS. Unos pronunciamientos en los que resulta llamativa cierta falta de precisión y, por tanto, de seguridad. En unos casos se apela al factum principis, pero este se vincula a que la decisión de la Administración contratante sea imprevisible. En otros, se acude directamente a la imprevisibilidad de la decisión, sin tomar en consideración el dato de que ha sido adoptada por una Administración distinta a la contratante. Y por si no fuera suficiente, la valoración de la imprevisibilidad o no de la decisión, tanto la de hacer como la de no hacer, termina encontrando respuestas contradictorias. De manera que el llamado factum principis como causa determinante del derecho del contratista al restablecimiento del equilibrio económico del contrato, en la versión parcial y limitada que reflejan los arts. 270.2.b) y 290. 4.b) LCSP, reclama una profunda reconsideración. Una reconsideración que seguramente debería llevar a su supresión para reconducirlo sin más a su sede conceptual propia y específica, que no es otra que la de la responsabilidad patrimonial extracontractual de la Administración ${ }^{26}$.

25 No otra cosa hizo la STS de 2 de diciembre de 2015 (rec. 3224/2015), que, ante la pretensión de la concesionaria de autopista de que se le reconociera el derecho a ser compensada por la disminución del trafico debida a la entrada en funcionamiento de unas vías de desvío («vías colectoras») que posibilitaban el mismo servicio que ofrecía el tronco del tramo concesional, en el fundamento de derecho 7 concluye que tales hechos "permiten identificar las notas con las que se viene configurando el «factum principis», ya que, por un lado revelan una actuación procedente de la propia Administración concedente y, por otro, ponen de manifiesto una evidente incidencia en uno de los hechos determinantes de la contraprestación que corresponde al concesionario, cual es el tráfico o número de vehículos que ha de ser tomado en consideración para fijar la subvención que como derecho se le reconoce en el contrato», añadiendo, asimismo, que "los casos considerados por esas sentencias de 16 de mayo de 2011 y 4 de febrero de 2014 de esta Sala y Sección que invoca el recurso de casación no son asimilables al aquí enjuiciado, pues la polémica en aquéllos estuvo referida a la previsibilidad o no de hechos ajenos a los contratantes o a actuaciones procedentes de una Administración diferente a la contratante».

26 Como ha explicado la doctrina, el fundamento de la indemnización del contratista por factum principis no es distinto al que sustenta la responsabilidad extracontractual de la Administración. Véase E. García de Enterría (1984), Los principios de la nueva Ley de Expropiación Forzosa, 2a ed., Madrid: Civitas, pág. 205. Lo reitera G. Ariño Ortiz (1968: 


\section{LA OBLIGACIÓN DE INCORPORAR AVANCES TÉCNICOS QUE MEJOREN LA PRESTACIÓN DEL SERVICIO}

Como hemos dicho, el derecho del contratista a desistir del contrato está específicamente previsto para el contrato de concesión de obras (art. 270.4 LCSP) y para el de concesión de servicios (art. 290.6 LCSP) en el supuesto de que al contratista le resulte extraordinariamente oneroso el cumplimiento del contrato a consecuencia de la aprobación de una disposición general por una Administración distinta de la concedente con posterioridad a la formalización del contrato [letra a) de los arts. 270.4 y 290.6, LCSP]. Pero junto a este supuesto, en la letra b) de los mismos artículos se añade este otro: "Cuando [el contratista] deba incorporar, por venir obligado a ello contractual o legalmente, a las obras o a su explotación [del servicio] avances técnicos que las mejoren notoriamente y cuya disponibilidad en el mercado se haya producido también con posterioridad a la formalización del contrato».

La obligación del contratista de incorporar los avances tecnológicos en la prestación del servicio, en la medida que conlleve una mayor onerosidad en la ejecución, solo da derecho al desistimiento del concesionario, sin perjuicio de que puede haberse previsto en el contrato y estar acompañada de alguna contrapartida económica por parte de la Administración contratante ${ }^{27}$. Nada impide, en efecto, que así se pacte, pero de no hacerlo el cumplimiento de la obligación que recae en el contratista no se traducirá en el correlativo derecho a obtener una compensación.

Por último, se ha venido considerando que el necesario reajuste de la prestación del servicio al progreso técnico no determina necesariamente la modificación del contrato, ya que la obligación de incorporar los avances técnicos — sin perjuicio de lo dispuesto en la legislación sectorial de los diversos servicios- se considera incluida implícitamente en los contratos de gestión de servicios públicos ${ }^{28}$. Cuestión distinta es que, al amparo del ius variandi, la Administración decida modificar las características del servicio objeto del contrato, pero, de ser así, el contratista tendrá derecho a la correspondiente indemnización.

264). Asimismo, T. Quintana López (1986: 269). También el Consejo de Estado (entre otros más, Dictamen 468/1984, de 4 de octubre).

El proceso de incorporación de la llamada cláusula de progreso a los contratos de gestión de los diversos servicios públicos, a partir del inicial conflicto del gas y la electricidad a principios del siglo Xx, ha sido estudiado por J. L. Meilán Gil (1968), La cláusula de progreso en los servicios públicos, Madrid: Instituto de Estudios Administrativos (posteriormente reeditado en 2006 con el título Progreso tecnológico y servicios públicos, Madrid: Civitas).

28 Por ejemplo, STS de 10 de mayo de 1988 (núm. 657, ROJ: 3480/1988), fundamento de derecho 5. 


\section{RIESGO Y VENTURA DEL CONTRATISTA ANTE RIESGOS IMPREVISTOS E IMPREVISIBLES}

Más allá de las excepciones al riesgo y ventura del contratista que acabo de referir - fuerza mayor y «actuaciones de la Administración contratante» que inciden en la economía del contrato-, en la LCSP no se prevé ninguna otra. Sí lo hace, como es notorio, el RSCL de 17 de junio de 1955, que acogió el riesgo imprevisible como una excepción al riesgo y ventura del concesionario de servicios públicos locales (arts. 126.2, 127.2, 128.1 y 3, y 129.3 y 5). Pero independientemente de que no está reconocido con carácter general, jurisprudencia y doctrina admiten que el riesgo y ventura también cede ante riesgos sobrevenidos imprevistos — considerando como tales a aquellos cuya falta de previsión no se debe a la ausencia de diligencia del contratista en orden a preverlos ${ }^{29}$ - y ante otros sencillamente imprevisibles por su carácter o naturaleza.

Fruto de un notable casuismo, en la jurisprudencia se localizan decisiones que han limitado el riesgo y ventura del contratista ante eventualidades o anomalías no previstas y circunstancias sobrevenidas de carácter imprevisible surgidas en la ejecución del contrato, y no solo en el de concesión de servicios, sino también en el de obras. Todos estos pronunciamientos, que reconocen al contratista un derecho indemnizatorio a pesar de carecer de base legal y contractual, justifican sus decisiones sencillamente en principios generales que van desde la cláusula rebus sic stantibus a la doctrina o teoría del riesgo imprevisible, o también, desde el enriquecimiento injusto y, en última instancia, la equidad, la buena fe y la justicia, a la conveniencia y necesidad de mantener la continuidad y regularidad del servicio público.

Sin embargo, este tipo de declaraciones, muy frecuentes hace treinta o cuarenta años, progresivamente han ido diluyéndose y aun cuando se siguen haciendo, al afirmarse que los riesgos imprevisibles dan lugar a que la Administración contratante asuma al menos parte de sus consecuencias económicas

29 Ha recordado T. R. Fernández Rodríguez (2016), «Los riesgos imprevistos en el contrato de obras», Revista de Administración Pública, 201, págs. 203 ss., que, en la doctrina francesa, "por sujeciones imprevistas hay que entender las «dificultades materiales de un carácter absolutamente anormal que no han podido entrar razonablemente en las previsiones de las partes en el momento de la conclusión del contrato y que hacen más onerosa la ejecución de éste». Además, «en las sujeciones imprevistas no es necesario llegar a la imposibilidad absoluta porque para apreciar su existencia es suficiente con que exista un incremento sustancial de la onerosidad" y normalmente juegan en el contrato de obras. Y en la pág. 206 puntualiza, asimismo, que las sujeciones imprevistas se distinguen también de la teoría de la imprevisión, pues «los acontecimientos susceptibles de poner en marcha la teoría de la imprevisión no tienen nada que ver con las prestaciones objeto del contrato, sino con fenómenos relativos al orden económico general que, al incidir sobre aquel, alteran gravemente el equilibrio económico que está en la base del negocio jurídico concluido». 
porque así lo exigen los principios de equidad y de buena fe, lo cierto es que, en la mayoría de las ocasiones, no pasan de ser consideraciones más teóricas que otra cosa, porque el hecho incuestionable es que la jurisprudencia normalmente niega que el pretendido riesgo imprevisible lo sea y que, por tanto, haya lugar a una compensación. En particular, frecuente ha sido la apelación al enriquecimiento injusto que se produciría de no accederse a reequilibrar la alteración de la equivalencia de las prestaciones contractuales como consecuencia de sobrevenir durante la ejecución del contrato circunstancias y hechos que no se tuvieron presentes, ni pudieron tenerse, en el momento de celebrarlo. Pero, como ha sido señalado por la doctrina ${ }^{30}$, la mezcla entre la doctrina del riesgo imprevisible y el enriquecimiento injusto ha dado lugar a confusiones y falta de seguridad. Junto a decisiones favorables, dando entrada al enriquecimiento injusto ${ }^{31}$, no faltan otras tantas en sentido opuesto ${ }^{32}$.

En definitiva, la utilización del principio de enriquecimiento injusto para justificar el mantenimiento del equilibrio económico del contrato es sumamente problemática e insegura, aparte de que conceptualmente tampoco encuentra una

30 De manera destacada, véase M. Rebollo Puig (1995), El enriquecimiento injusto de la Administración Pública, Madrid: Marcial Pons, págs. 135 ss.

31 Por ejemplo, STS de 30 de marzo de 1991 (ar. 2022), en relación con la necesidad de adoptar mayores precauciones de las previstas al realizar los taludes de las excavaciones y trasladar a un vertedero los materiales extraídos, así como la aparición, de forma inesperada, de roca en el terreno. También, STS de 20 de marzo de 1985 (ar. 2841), con ocasión de dificultades en la ejecución no previstas que originaron mayores desembolsos por parte del contratista, manteniendo que "[...] siendo, en fin, lo decisivo que la empresa ha rendido unas obras [...] y que se prueben como aquí lo están las dificultades aparecidas en su ejecución, en un principio no previsibles, en estos casos, pugnaría con la Justicia y no sería conforme a Derecho [...] que se beneficiara de ello la otra parte contratante, librándose del pago, porque no se puede consentir la consumación de un desequilibrio económico».

Recuerda M. Rebollo Puig (1995: 146) que la STS de 17 de marzo de 1970 (ar. 1551) rechazó la indemnización pretendida como consecuencia del mayor coste debido a dificultades imprevistas en la ejecución del contrato de obra (aparición de una veta de rocas en el movimiento de tierras, dificultades en los trabajos de desmonte, terraplenado y remoción de tierras), ya que para la invocación del enriquecimiento sin causa de la Administración sería necesario que «el contratista hubiese realizado obras necesarias para el cumplimiento del contrato, no previstas en el proyecto». Sin embargo, como bien señala el referido autor, «en los supuestos incluibles en las sujeciones imprevistas faltaría siempre el segundo requisito, ya que, por hipótesis, se trata de realizar las obras previstas en el proyecto». Y aún añade: «Pero no puede dejar de reconocerse alguna justificación a la negación de enriquecimiento injusto en estos supuestos: no recibe la Administración nada a lo que no tuviera derecho en virtud del contrato, sino justamente lo que en virtud de éste le correspondía; no hay una transferencia de valor sin justificación jurídica alguna. Eso solo sucedería —como indica la sentencia - ante obras no previstas en el proyecto». Una síntesis de los requisitos del enriquecimiento injusto que exige la jurisprudencia puede verse en STS de 17 de mayo de 2012 (rec. 4003/2008), fundamento de derecho 13. 
explicación satisfactoria. Considerar que se produce un enriquecimiento injusto de la Administración si esta no indemniza, presupone que la consecuencia económica del desequilibrio por causas imprevisibles $-\mathrm{o}$, incluso, no previstasinevitablemente queda al margen del riesgo y ventura del contratista, porque, en caso contrario, nunca podría afirmarse que la no indemnización determina dicho enriquecimiento. De manera que el recurso dialéctico del enriquecimiento injusto no solo no solventa nada, sino que perturba y oscurece la cuestión de principio a la que hay que dar respuesta, y que no es otra que la de decidir «hasta dónde llega el principio del riesgo y ventura y dónde comienzan las exigencias del mantenimiento del equilibrio económico del contrato» ${ }^{33}$.

Corresponde, pues, al legislador o, en la medida en que la ley lo permita, a las partes contratantes en ejercicio de la libertad de pactos que se les reconoce, esa determinación o concreción del riesgo, lo que, como es lógico, será el resultado de la ponderación de criterios diversos, tanto de equidad como de eficacia u oportunidad y otros posibles. Pero una vez concretada la asignación de los riesgos, no cabe pretender corregirla o alterarla a la vista de las circunstancias de cada caso concreto y en atención a un pretendido enriquecimiento injusto de la Administración.

Es preciso añadir que cuando se admite que el riesgo imprevisible da paso a la obligación de la Administración de restablecer el equilibrio del contrato, no faltan discrepancias acerca del alcance que la misma ha de tener, si bien la opinión mayoritaria se inclina, tanto en la jurisprudencia como en la doctrina, a considerar que, a diferencia del desequilibrio resultante del ejercicio de la potestas variandi e, incluso, del factum principis, la garantía se ha de traducir en una compensación parcial, nunca integral o plena ${ }^{34}$.

Por lo demás, en líneas generales la jurisprudencia refleja una inequívoca tendencia a considerar muy restrictivamente la concurrencia de circunstancias y hechos imprevisibles que dan lugar al reconocimiento del derecho del contratista a obtener de la Administración una compensación parcial por daños y perjuicios. A lo largo del tiempo se encuentran, a este respecto, declaraciones claras y contundentes.

En numerosas ocasiones se ha declarado que el aumento de los costes salariales no es un riesgo imprevisible que pueda dar lugar al restablecimiento del equi-

33 La expresión es de M. Rebollo Puig (1995: 156).

34 En este sentido, por ejemplo, STS de 25 de abril de 1986 (ar. 2963), con directo apoyo en la de 11 de julio de 1978, que fue comentada por L. Parejo Alfonso (1978), «¿Un paso atrás en la doctrina del riesgo imprevisible?», Revista Española de Derecho Administrativo, 18, págs. 446 ss., criticando la exclusión en la compensación del normal beneficio industrial, a diferencia del criterio mantenido en la anterior STS de 6 de junio de 1975. Posteriores sentencias ratificaron definitivamente el referido criterio [por ejemplo, SSTS de 21 de octubre de 1980 (ar. 4005), de 23 de diciembre de 1981 (ar. 5295), de 14 de marzo de 1985 (ar. 1592), la ya citada de 25 de abril de 1986 (ar. 2963), de 9 de octubre de 1987 (ar. 8326), de 17 de julio de 1991 (ar. 6171), de 23 de febrero de 2001 (rec. 3856/1995), etc.]. 
librio económico-financiero del contrato ${ }^{35}$. También se ha rechazado que pueda calificarse como riesgo imprevisible «el hecho del cierre de una servidumbre de paso por parte del titular del terreno donde era necesario el tránsito a efectos de ejecutar la obra ${ }^{36}$. E, igualmente, se ha estimado que el incremento de los justiprecios expropiatorios en virtud de decisiones judiciales, que aumentan el coste previsto de la ejecución de contratos de concesión de obras públicas - construcción de autopistas-, da lugar o no al restablecimiento del equilibrio económico-financiero en función de lo que en los pliegos se haya previsto ${ }^{37}$, sin que, en caso de no haberse incorporado a los mismos previsión alguna, se dé entrada al riesgo imprevisible como excepción al riesgo y ventura del concesionario ${ }^{38}$. En fin, la misma posición restrictiva ante el riesgo imprevisible se evidencia con ocasión de la suspensión de una obra ordenada judicialmente a raíz del ejercicio de una acción interdictal por parte de un tercero ${ }^{39}$.

Por otra parte, los numerosos asuntos relativos al incremento de los precios de los ligantes asfálticos ponen de manifiesto cómo la jurisprudencia modula sus apreciaciones en función de las circunstancias de cada caso. La STS de 16 de septiembre de 1988 (rec. 15049/1983), fundamento de derecho 3, con cita de otras anteriores —en especial, STS de 12 de diciembre de 1979—, es un ejemplo palmario del revoltijo de principios - justicia, equidad, buena fe, rebus sic stantibus, riesgo imprevisible, incluso «empobrecimiento injusto del contratista»— a los que, de vez en cuando, se acude para dejar sin efecto el principio de riesgo y ventura del contratista. En esta ocasión, a pesar de que las cláusulas del contrato

35 Entre otras, SSTS de 23 de septiembre de 1981 (ar. 5295), de 18 de diciembre de 2000 (rec. 5223/1996), de 23 de febrero de 2001 (rec. 3856/1995), de 9 de diciembre de 2003 (rec. 4361/1988), de 4 de mayo de 2005 (rec. 1094/2003), etc.

38 Caso, por ejemplo, de las SSTS de 6 de noviembre de 2015 (rec. 2785/2014) y de 28 de abril de 2016 (rec. 2758/2014). Cuestión distinta es que, ante el impago del justiprecio por la concesionaria en situación de concurso de acreedores, la STS de 17 de diciembre de 2013 (rec. 1623/2013) confirmara la condena al Estado como responsable subsidiario, así como en otras posteriores: SSTS de 18 de noviembre de 2014 (rec. 1261/2014), de 18 de febrero de 2016 (rec. 344/2016), etc. Y de ahí que, además de las medidas adoptadas por la disposición adicional $41^{\text {a }}$ de la Ley 26/2009, de 23 de diciembre, de Presupuestos Generales del Estado para 2010 — a la que más adelante me referiré-, el Real Decreto Ley 1/2014, de 24 de enero (arts. 6 y 7, modificando el art. 271 TRLCSP de 2011), viniera a disponer que si el concesionario no cumple la obligación de satisfacer las indemnizaciones por razón de las expropiaciones y ocupaciones temporales para la ejecución del proyecto y el Estado tiene que hacerse cargo del abono de las mismas a los expropiados, "desde el momento en que se declare la obligación de pago a cargo del Estado, las cantidades que no le sean reembolsadas [por el concesionario] minorarán el importe global que corresponda en concepto de responsabilidad patrimonial de la Administración».

39 Véase la STS de 31 de octubre de 2000 (rec. 3419/1996). 
no habían previsto la revisión de precios, la sentencia salva el escollo afirmando que «ello fue debido a la corta duración del mismo, que no hacía suponer su necesidad». Y seguidamente se afirma que:

[...] en curso de la ejecución del contrato se produjo una brusca e inesperada subida en el mercado de los precios de los «crudos», de cuya materia se obtienen los «ligantes asfálticos» [...], lo que supuso, por imprevisible, una situación de crisis en la economía de aquellas contrataciones en las que los aludidos productos tenían una importancia de primer orden [...]; de aquí que [...] la figura jurídico-doctrinal de la cláusula «rebus sic stantibus» o la de «riesgo imprevisible» [...] pueden legitimar una "revisión de precios», no pactada, cuando en las vicisitudes de la contratación concurran unas circunstancias y alteraciones económicas extraordinarias y anormales, imprevistas y profundas, que afecten gravemente al contratista que actuó de buena fe y dentro de unas previsiones razonables; pues, frente al principio general «pacta sunt servanda» llevado a sus últimos y exagerados términos, «sumun ius summa injuria», en aras de una formalística «seguridad jurídica», se impone en el derecho administrativo el principio del "valor superior de la justicia» proclamado en el párrafo 1, del art. 1. ${ }^{\circ}$, de la Constitución Española de 1978, ya que no se debe desconocer que en las relaciones entre la Administración y los ciudadanos, aquélla debe actuar en el campo estricto del Derecho administrativo, más que en el de sus intereses patrimoniales, estando dichas relaciones jurídicas marcadamente influenciadas por los principios de «equidad» $\mathrm{y}$ «buena fe», los cuales exigen mitigar la excesiva, y por lo tanto antijurídica, onerosidad no necesaria de las prestaciones de los ciudadanos, cuando hechos o eventos transcendentales, extraordinarios o inéditos concurren en sus situaciones jurídicas, cual ocurre en el caso presente que nos ocupa ${ }^{40}$.

Sin embargo, las SSTS de 18 de abril de 2008 (rec. 5033/2006), de 25 de abril de 2008 (rec. 5038/2006), de 6 de mayo de 2008 (rec. 5111/2006), de 4 de junio de 2008 (rec. 5093/2006), de 27 de octubre de 2009 (rec. 763/2007), de 10 de noviembre de 2009 (rec. 930/2007), hasta llegar a la más reciente de 9 de septiembre de 2020 (rec. 2394/2016), aun cuando no niegan en abstracto que la subida de precios pueda ser calificada como un hecho imprevisible que no pudo ser tenido en cuenta al tiempo de celebrarse el contrato, consideran, no obstante, que los precios de los productos derivados del petróleo se encontraban ya liberalizados en virtud de la Orden Ministerial de Hacienda de 1 de octubre de 1986 y su posible subida era un riesgo posible, al igual que un beneficio si bajaban, sin que quepa admitir que la imprevisión del contratista pueda justificar una eventual compensación por el incremento de los materiales. Así pues, en el cambio de las circunstancias justifica el TS que su respuesta sea distinta a la que se dio en las iniciales sentencias, sin que se deba a un cambio de doctrina.

40 En el mismo sentido, SSTS de 20 de diciembre de 1990 (ar. 10542), de 27 de diciembre de 1990 (ar. 10151), de 17 de abril de 1991 (ar. 3486), de 17 de diciembre de 1997 (rec. 3099/1882), y de 19 de enero de 1998 (rec. 1290/1990). 
Por último, la tendencia jurisprudencial a considerar de manera restrictiva el riesgo imprevisible se refleja, asimismo, en las SSTS de 4 de febrero de 2006 (rec. 192/2003) ${ }^{41}$ y de 16 de julio de 2019 (rec. 308/2016) (2 $^{42}$ así como en las numerosas sentencias que, como ya hemos dicho, han mantenido de manera constante que «la merma de flujos de vehículos no constituye un riesgo imprevisible, sino una consecuencia reconducible al principio de riesgo y ventura que rige la contratación administrativa» y que «[...] tampoco debe considerarse fuera de lo previsible que esa mejora consista en desdoblar las calzadas conforme se incrementa el tráfico pues se viene haciendo desde hace años en distintas vías o tramos de vías». No se está, pues, ante hechos extraordinarios e imprevisibles que deban quedar fuera del riesgo y ventura del contratista ${ }^{43}$.

Es verdad, no obstante, que, como excepción, algunas sentencias han apreciado la existencia de un efectivo riesgo imprevisible. Sin perjuicio de que probablemente se puedan localizar otras más -ya que en esta ocasión revisar más de sesenta años de jurisprudencia, a partir del RSCL de 1955, no resulta posible-, al menos pueden recordarse las dos siguientes.

La STS de 15 de octubre de 2012 (rec. 1554/2011), ante la pérdida del beneficio - una bonificación fiscal— previsto en el contrato de concesión por

41 En relación con la evolución negativa de un mercado como el de la televisión de pago, afirma la sentencia que «no puede calificarse ni sobrevenida, por razones técnicas derivadas de la evolución del mercado tecnológico, ni imprevisible, pues las necesidades de instalación eran predecibles desde el inicio de las emisiones de una televisión privada de pago con una nueva tecnología en el modo de transmitir la señal». Y aún añade que «tampoco puede calificarse de circunstancia sobrevenida la situación puesta de manifiesto por no haber captado la recurrente los clientes inicialmente previstos ni tampoco haber sabido mantenerlos o fidelizarlos».

42 En el fundamento de derecho 4 concluye que «en este caso, esas medidas encaminadas a reequilibrar la ecuación financiera del contrato no encuentran amparo en esos supuestos tasados, previstos en la sucesiva legislación de los contratos públicos, ya que ese descenso exponencial de la demanda de VPO en Álava — apreciada ya en 2006fue una manifestación más de los efectos de la crisis económica que se inició en el verano de 2007, instaurándose de forma inequívoca a partir de 2008; luego en la fecha en la que se adjudicó a la mercantil el derecho de superficie sobre las dos fincas propiedad del Gobierno Vasco para la construcción, urbanización y venta de 36 viviendas de VPO, adjudicándole los beneficios de la promoción —-finales de 2009- la precaria situación económica era una realidad incuestionable que no cabe calificar de riesgo imprevisible (como reconoce la propia sentencia recurrida) [...]».

43 Véase SSTS de 16 de mayo de 2011 (rec. 566/2008), 20 de junio de 2011 (rec. 62/2009), 19 de diciembre de 2011 (rec. 159/2010), 25 de enero de 2013 (rec. 4887/2011), 4 de febrero de 2014 (rec. 486/2011), 28 de enero de 2015 (rec. 449/2012), 20 de abril de 2015 (rec. 54/2013), 17 de noviembre de 2015 (rec. 2969/2014), 12 de mayo de 2016 (rec. 451/2012), 13 de junio de 2017 (rec. 2266/2015), 17 de octubre de 2017 (rec. 446/2012), 19 de febrero de 2018 (rec. 3310/2015), y la más reciente de 22 de mayo de 2019 (rec. 904/2015)]. 
razón de su anulación en virtud de sentencia, tras recordar que ya se habían pronunciado al respecto las SSTS de 29 de noviembre de 2011 (rec. 4589/2008), de 12 de diciembre de 2011 (rec. 4849), de 17 de septiembre de 2012 (rec. 606/2010) y de 8 de octubre de 2012 (rec. 1405/2009), reitera que no se trata de un incumplimiento contractual, pues la Administración contratante nada ha incumplido, ya que queda obligada, sin más, a cumplir con la sentencia que ha declarado ilegal el beneficio fiscal acordado, y que, por eso mismo, la nueva situación determinante de la alteración del equilibrio económico-financiero de la concesión es fruto de una circunstancia sobrevenida imprevisible que da derecho a la empresa concesionaria a ser compensada ${ }^{44}$. E, igualmente, la STS de 1 de julio de 1992 (núm. 2339, ROJ: 5319/1992), que en relación con el aumento del número de usuarios del servicio de recogida de basuras de un municipio turístico considera que se trata de un hecho imprevisible, por lo que, al provocar una mayor onerosidad en la ejecución del contrato —ya que la retribución del contratista no lo era con cargo a las tarifas de los usuarios, sino que consistía en un precio pactado_-, el contratista ha de ser compensado económicamente por la Administración contratante ${ }^{45}$.

En definitiva, no parece que toda esta problemática esté, en estrictos términos jurídicos, bien resuelta. La jurisprudencia, a pesar de lo dispuesto por la regulación legal vigente — con la excepción, si acaso, de las previsiones del RSCL, en la medida que sigan vigentes y no hayan quedado desplazadas por la legislación básica estatal_, viene manteniendo una doctrina que, aun cuando lo sea, en términos generales, más en un plano teórico que práctico, le sirve en ocasiones para terminar reconociendo, con no poca dosis de voluntarismo, un derecho que

44 De todas formas, la cuestión no puede darse por definitivamente resuelta, ya que el ATS de 6 de mayo de 2021 ha admitido a trámite el recurso de casación 7119/2019, al considerar que reviste interés casacional «la determinación del significado y alcance de la doctrina del factum principis y sus efectos sobre la economía del contrato, y, en detalle, si la sobrevenida sujeción al pago del impuesto sobre bienes inmuebles por parte del concesionario comporta inexorablemente la ruptura del equilibrio económico- financiero del contrato o si, por el contrario, la desaparición de la exención al pago de dicho impuesto local, operada por norma con rango de ley, se inscribe en el principio de riesgo y ventura y no determina el nacimiento de derecho a compensación alguno a cargo de la Administración contratista. Y ello, atendiendo especialmente a la existencia de fallos contradictorios de distintas Salas territoriales en torno a la cuestión controvertida».

En esta ocasión, a pesar de tratarse de un municipio turístico, no se estima que fuera previsible el aumento de las prestaciones. Por otro lado, fácilmente se constata que la calificación de concesión para un contrato en el que el gestor del servicio percibe su retribución mediante un precio a tanto alzado a cargo de la Administración y no de las tarifas resultantes de la explotación del servicio, resulta inadecuada y, por ello mismo, inadecuada es también la proyección del principio del equilibrio económico-financiero alterado por causas ajenas a la acción —u omisión— de las partes contratantes a un contrato de tales características. 
el legislador no reconoce ${ }^{46}$. Y es que, como bien apunta la STS de 6 de noviembre de 2015 (rec. 2785/2014), fundamento de derecho 9:

[...] es posible que los intereses generales hagan aconsejable la continuidad de determinadas concesiones a pesar de las dificultades financieras de sus titulares y a pesar de que legalmente no les asista el derecho a reclamar medidas de reequilibrio; en estos casos el poder público puede acordar medidas para lograr esa continuidad, pero esas medidas no tendrán como finalidad dar satisfacción a un derecho preexistente del concesionario al reequilibrio, sino una medida de política general dirigida a la atención de unas concretas necesidades públicas cuya constatación o ponderación a dicho poder público corresponde.

Por lo demás, ya se ha anticipado que el hecho de que, a excepción de la fuerza mayor, la legislación de contratos no excluya del riesgo y ventura del contratista los llamados riesgos imprevisibles no significa que, cuando los mismos se produzcan, el legislador no intervenga dando entrada a ciertos paliativos. Dejando al margen la técnica de la revisión de precios, finalmente generalizada como un mecanismo previsor de desequilibrios económicos que es sabido se producen de manera irremisible — sobre todo en contratos sujetos a plazos de ejecución de larga duración-, no otro es el caso de las medidas legislativas adoptadas en los últimos años para subvenir en parte los déficits producidos en las concesiones de obras (autopistas) como consecuencia del incremento de los costes de las expropiaciones y de obras adicionales. Unas medidas consistentes en el establecimiento de los llamados «préstamos participativos» y de la «cuenta de compensación» ${ }^{47}$, que, por otra parte, han generado una notable conflictividad sobre la que la Sala Tercera del TS ha tenido que pronunciarse en reiteradas ocasiones ${ }^{48}$. Y todo ello sin

46 También la STS de 4 de julio de 2003 (rec. 6360/1997) desestima el recurso de casación contra la sentencia de instancia que reconoció el derecho de la concesionaria a ser indemnizada por AENA, en concepto de lucro cesante, y por exceso del canon, como consecuencia de la quiebra del equilibrio financiero de la concesión para la explotación de los servicios de restaurante, bar y cafetería del aeropuerto de Gran Canaria, debida a causas como la disminución del número de usuarios del servicio concedido por la crisis del sector turístico a consecuencia de la guerra del Golfo, aunque también por las obras de remodelación del aeropuerto en 1993, que produjeron el cierre de la cafetería y bar.

47 No otra cosa ha sucedido con las concesiones de autopistas: véase la disposición adicional 41 a de la Ley 26/2009, de 23 de diciembre, de Presupuestos Generales del Estado para 2010, y disposición adicional $8^{a}$ de la Ley 43/2010, de 30 de diciembre, del servicio postal universal, de los derechos de los usuarios y del mercado postal, modificada por la disposición final $21^{\text {a }}$ de la Ley 17/2012, de 27 de diciembre, de Presupuestos Generales del Estado para el ańo 2013.

48 No hay lugar ahora a adentrarse en el análisis de esa jurisprudencia. Baste decir que, en relación a la cuenta de compensación, según reiterada doctrina, la misma queda condicionada a que haya consignación presupuestaria, sin que exista por tanto el reconocimiento de un derecho incondicional al otorgamiento de tales compensaciones. La STS de 28 de 
perjuicio de intervenciones legislativas, incluso aún más singularizadas, como las adoptadas respecto del frustrado proyecto Castor ${ }^{49}$.

A la vista de intervenciones de este tipo, que se siga proclamando el riesgo y ventura del contratista en las concesiones de obras y de servicios puede parecer, ciertamente, un sarcasmo. De ahí la elegía que ya se le ha brindado ${ }^{50}$. Pero tampoco puede sorprender. A la postre, cuando no prosperan proyectos de gran envergadura económica que nunca deberían haberse emprendido o, en todo caso, deberían haberlo sido en otros términos, resulta ingenuo pensar que la solución vendrá de la mano de imputar sin más al contratista las consecuencias económicas de los mismos. La «socialización» del fracaso económico, dadas sus magnitudes e implicaciones, termina imponiéndose. La experiencia bien lo acredita. Como también acredita que solo la prevención y el control anticipado de lo que se pretende hacer pueden evitar fiascos semejantes.

abril de 2015 (rec. 295/2013), ya lo dejó dicho y lo han repetido, hasta la saciedad numerosas sentencias, tal como se puede ver en la exhaustiva relación que contienen las dos últimas SSTS de 13 y 14 de febrero de 2020 (recs. 2950/2016 y 2947/2016). Y respecto de los préstamos participativos, en STS 13 de junio de 2017 (rec. 2266/2015), fundamento de derecho 7, se recuerda lo dicho en STS de 9 de mayo de 2016 (rec. 517/2013): «Dada su especial naturaleza centrada en la condición de crédito, la eventual demora en el otorgamiento del préstamo no genera intereses si no lo prevé una norma, lo que aquí no acontece». Asimismo, las SSTS de 10 de mayo de 2016 (rec. 264/2014) y de 31 de mayo de 2016 (rec. 549/2012), hasta llegar a la de 20 de febrero de 2020 (rec. 2779/2018), han declarado que la concesionaria, al haber sido declarada en concurso de acreedores, no tiene derecho a obtener del Estado los préstamos participativos por sobrecostes de expropiaciones. Además, las SSTS de 12 de febrero de 2020 (rec. 2640/2017), de 18 de febrero de 2020 (rec. 4353/2017), y de 19 y 25 de enero de 2021 (recs. 3831/2018 y 2589/2018) han precisado que el saldo de compensación anual y demás derechos de cobro de la concesionaria de autopistas debe ser contabilizado como inmovilizado intangible y no como activo financiero. Y lo mismo sucede con los intereses de derivados de las medidas de reequilibrio económico previstas en el Real Decreto 907/2011, ya que no pueden ser considerados como «activo en balance» [STS de 4 de febrero de 2021 (rec. 2369/2019), que reitera la doctrina de la inicial STS de 18 de febrero de 2020, ya citada, y siguientes SSTS de 15, 18, 19 y 26 de enero de 2021 (recs. 5177, 2750 y 7432/ 2018, y 1062/2019, respectivamente)].

49 Véase el análisis de Fuertes López (2018: 13 ss.). Cabe añadir que el desenlace final de este asunto ha venido de la mano de la STS de 27 de octubre de 2020 (rec. 1404/2020), que ha reconocido el derecho del Banco Santander, S.A., CaixaBank, S.A. y Bankia, S.A., a ser indemnizados por el Estado con 1.350,729 millones de euros, Y en ejecución de la misma se ha dictado el Real Decreto Ley 39/2020, de 29 de diciembre, de medidas financieras de apoyo social y económico y de cumplimiento de la ejecución de sentencias, disponiendo que «al objeto de proceder al pago de la ejecución de la citada sentencia, se concede una ampliación de crédito por importe de 638.000.000 de euros».

Fuertes López (2018). 


\section{RIESGO Y VENTURA DEL CONTRATISTA ANTE EL EJERCICIO DE PODERES CONTRACTUALES DE LA ADMINISTRACIÓN}

Hemos advertido que el contratista ningún riesgo asume cuando la mayor onerosidad de la ejecución del contrato se debe al ejercicio de los poderes extraordinarios que la ley atribuye a la Administración en orden a su modificación. Aunque también los contratos públicos han de cumplirse a tenor de sus cláusulas, el art. 189 LCSP de inmediato puntualiza que tal regla lo es «sin perjuicio de las prerrogativas establecidas por la legislación a favor de las Administraciones Públicas». Y, entre otras manifestaciones de esos poderes, en lo que ahora interesa, la Administración puede modificar los contratos por razones de interés público y puede suspender su ejecución, sin perjuicio de disponer, además, de un poder de dirección respecto del contratista, al cual puede dirigir órdenes e instrucciones relativas a la forma y manera de ejecutar las prestaciones que le obligan (art. 190 LCSP) ${ }^{51}$.

Dejando en este momento al margen los poderes de dirección y de suspensión de la ejecución, conviene recordar que hasta la aprobación de la LCSP de 2007, la Administración dispuso de un amplio poder para modificar unilateralmente el contrato administrativo, por cuanto bastaba que concurriesen causas imprevistas o necesidades nuevas para que, cumpliendo algunos otros requisitos, la modificación se pudiera hacer efectiva. Sin embargo, a partir de ese momento se introdujo una rectificación de calado derivada del derecho de la Unión Europea y, en concreto, de la necesidad de salvaguardar los principios de igualdad de trato, no discriminación y transparencia derivados del art. 2 de la Directiva 2004/18/CE del Parlamento Europeo y del Consejo, de 31 de marzo de 2004, sobre coordinación de los procedimientos de adjudicación de los contratos públicos de obras, de suministro y de servicios. De manera que ha quedado establecido que solo se admitirá la modificación del contrato cuando así se hubiera previsto en los pliegos o en el anuncio de licitación, o, en otro caso, en los supuestos y con los límites establecidos directamente por la ley (en la actualidad, arts. 203 a 207 LCSP).

Pues bien, quedando el riesgo y ventura del contratista al margen de los dańos y perjuicios que pueden derivar de la acción de las partes contratantes ${ }^{52}$, resulta sorprendente que en los arts. 203 a 207 LCSP no haya previsión alguna

51 Al regular los distintos tipos de contratos administrativos se reiteran algunas de esas prerrogativas (arts. 238.1, por relación al contrato de obras, 261.1_en relación con los contratos de concesión de obras, 290, respecto del contrato de concesión de servicios).

52 Entre otras, la STS de 24 de diciembre de 1997 (ar. 9622) lo expresa de forma clara y terminante: «El contratista asume la obligación de ejecutar la obra conforme al precio pactado, aceptando el riesgo de que a lo largo del contrato su ejecución resulte más gravosa por cualquiera circunstancias que no sean debidas a fuerza mayor, pero ese riesgo no incluye las alteraciones que sean debidas al ejercicio por la Administración de su «ius variandi», que han de ser debidamente indemnizadas para mantener el equilibrio de las prestaciones originariamente pactadas». 
de carácter general relativa a las consecuencias indemnizatorias vinculadas a los daños y perjuicios que resulten de la modificación de los contratos cuando esta sea obligatoria para los contratistas. Solo por relación al contrato de obras, de una parte (art. 242 LCSP), y respecto de los contratos de concesión de obras y de concesión de servicios, por otra [arts. 270.2.a) y 290.4.a) LCSP, al regular el llamado principio de equilibrio económico-financiero de las concesiones], se establecen unas reglas específicas. Pero la garantía del equilibrio económico-financiero del contrato como contrapuesta al riesgo y ventura resulta cuando menos equívoca, pues si con la modificación se altera la equivalencia de las prestaciones, la Administración debe proceder a restablecerla necesariamente mediante la correspondiente indemnización, por razón sin más de la necesaria observancia del pacta sunt servanda. El principio del equilibrio económico-financiero nada nuevo añade a lo que ya resulta de la propia naturaleza del contrato.

Por lo demás, no toda modificación da lugar a la correspondiente indemnización o compensación en favor del concesionario. El art. 270.5 LCSP, expresamente dispone, con carácter general, que «en el caso de que los acuerdos que dicte el órgano de contratación respecto al desarrollo de la explotación de la concesión de obras carezcan de trascendencia económica el concesionario no tendrá derecho a indemnización o compensación por razón de los mismos». Y lo mismo reitera el art. 290.3 LCSP para la concesión de servicios ${ }^{53}$.

La doctrina jurisprudencial, en líneas generales, confirma todo lo que se acaba de señalar. Por todas, baste remitir a la reciente STS de 19 de febrero de 2020 (rec. 626/2017) ${ }^{54}$, que, en relación con una modificación del régimen tarifario de una concesión de autopista por razón de que la implantación del sistema de "peaje en la sombra» acordado en su momento produjo un aumento del tráfico, y con ello los importes abonados por la Administración a la concesionaria se incrementaron sustancialmente respecto de los que debería haber abonado de no haberse cambiado el sistema inicial de abono directo del peaje por el usuario, concluye que dicha modificación resulta disconforme a derecho y la anula ${ }^{55}$.

53 Siendo obvio que cuando la modificación carece de trascendencia económica no procederá el reconocimiento de compensación económica, en alguna ocasión, tal como sucede en la STS de 20 de junio de 2011 (rec. 62/2009), parece identificarse —indebidamente, a mi juicio- la intrascendencia económica con el hecho de que la modificación no provoque pérdidas, aunque pueda suponer un menor beneficio para el contratista. No otra cosa cabe deducir de la afirmación (fundamento de derecho 6) de que el concesionario «indica lo que ha dejado de ganar, pero no justifica haber sufrido pérdidas» (con ocasión de la modificación de una concesión de autopista), por lo que se desestima la pretensión de que se anule la modificación y se sustituya por otra en la que se reconozca el derecho a cobrar el correspondiente peaje.

54 Ha sido comentada por Santamaría Pastor (2021).

55 Ante la singularidad de la revisión de las condiciones económicas de los conciertos sanitarios en aplicación del art. 90.4 de la Ley 14/1986, de 25 de abril, General de Sanidad, la STS de 30 de octubre de 2019 (rec. 2717/2017) también declara que la rebaja de los 
Ahora bien, tratándose de una doctrina jurisprudencial tan firmemente asentada y consolidada, no deja de ser un tanto sorprendente que la STS de 12 diciembre de 2019 (rec. 1558/2016) ${ }^{56}$, haya venido a avalar la legalidad de la modificación consistente en reducir la cuantía de las tarifas vigentes de los contratos de concesión de servicios de ITV por considerarse desproporcionado el beneficio de las entidades concesionarias resultante del mayor número de vehículos sujetos a inspección como consecuencia del progresivo envejecimiento del parque automovilístico. Aunque la sentencia mantiene (fundamento de derecho 4) que «la posibilidad de obtener una modificación del equilibrio económico-financiero del contrato, con su consiguiente reequilibrio, no juega - se insiste- en favor de la Administración, pues tal posibilidad resulta de aplicación, exclusivamente, en beneficio del concesionario ${ }^{57}$, de inmediato puntualiza que «al margen de los razonamientos de la sentencia sobre la doctrina del riesgo imprevisible, lo cierto es que la Orden impugnada - y la sentencia que revisamos, de forma explícita - fundamentan la reducción de las tarifas en los citados artículos 74 del TALCE y 221 del RGCE por existir una razón de interés público». De este modo, el TS considera que concurre «interés público» en la modificación a la baja de la cuantía de las tarifas y concluye declarando conforme a derecho la decisión cuestionada.

Sin embargo, yerra la sentencia al justificar la modificación en la necesidad de recomponer el régimen económico-financiero de las concesiones alterado por el devenir de la explotación, al registrarse un mayor número de usuarios al previsto o pronosticado en el momento de la formalización del contrato. Y yerra, asimismo, cuando afirma que se pactó un beneficio empresarial que debe ser restablecido a su estado original.

precios unitarios establecidos en el pliego de condiciones particulares acordada por la Administración supone una modificación unilateral del contrato que debe ajustarse a la legislación de contratos, por lo que, al no haberse previsto en dicho pliego la posibilidad de aplicar los nuevos precios sin compensación alguna, esta resulta obligada. Y lo reitera la STS de 17 de junio de 2020 (3326/2018).

56 También comentada por J. A. Santamaría Pastor (2021).

57 Ya se ha advertido que tanto el art. 270.2 como el art. 290.4 LCSP, expresamente disponen que el restablecimiento del equilibrio lo será «en beneficio de la parte que corresponda», con lo que queda desmentida la afirmación general de la sentencia. Aunque así lo fuera en otro momento, conviene tener en cuenta que no lo es en la actualidad. Hay que tener en cuenta que la precisión de que el reequilibrio lo será «en beneficio de la parte que corresponda" se estableció por la Ley 13/2003, que se incorporó al TRLCAP de 2000, manteniéndose en la LCSP de 2007 y en la vigente de 2017. Ello puede explicar que en la jurisprudencia a la que sigue remitiéndose el TS se afirmase que el reequilibrio solo opera en beneficio del concesionario. Pero, por eso mismo, esas remisiones resultan equívocas si no se advierte seguidamente de los cambios legales producidos, aunque los mismos no sean de aplicación al caso enjuiciado por razón del régimen transitorio aplicable al correspondiente contrato. 
Bastará decir, al respecto, que el régimen económico del contrato no se altera por el hecho de que los resultados económicos que depare su ejecución sean unos u otros. Son dos planos que, en estrictos términos jurídicos, no deben ser confundidos, ya que hay que estar a la equivalencia acordada en el contrato $^{58}$. De manera que la compensación al contratista por concurrir alguna de las excepciones a la regla del riesgo y ventura no determina la modificación del contrato, sino el estricto cumplimiento de una obligación legal ${ }^{59}$. Es precisamente la modificación del contrato que altera el equilibrio la que da lugar a la compensación, y no al revés, por lo que aquella solo procede cuando concurran los presupuestos legales, y entre ellos, desde luego, no se prevé el del perjuicio o beneficio del contratista en la explotación del servicio. Y, por otra parte, tampoco se pactó un beneficio empresarial, sino que se estimó o calculó un beneficio empresarial que, en conjunción con el pronóstico o prognosis del número de usuarios, del coste del servicio y la amortización de las inversiones necesarias para prestarlo, así como el plazo concesional, sirvieron para la determinación inicial de la cuantía de la tarifa.

En consecuencia, la sentencia conduce, sencillamente, a que el riesgo y ventura quede absolutamente erradicado o privado de toda significación y efectividad. En este caso, lo queda desde la consideración de la ventura del concesionario. En otros, manteniendo la coherencia, llevaría a que lo quedase desde la perspectiva del riesgo. Pero es evidente que, al menos en la regulación legal del contrato administrativo - en cualquiera de sus tipos, incluidos los contratos de concesiones-, ese entendimiento del principio del equilibrio económico no es el que se sanciona. Solo si la configuración legal de los contratos de concesión respondiese al principio de «cobertura suficiente»y, como contrapartida, al de «beneficio controlado» del concesionario, quedando con ello desplazado el riesgo y ventura, sería explicable una respuesta como la que el TS da a la cuestión planteada. Pero, como ya hemos visto, la legislación de contratos del Estado nunca lo ha previsto. Más aún. Con arreglo a la regulación vigente, que expresamente prohíbe la traslación a la Administración del riesgo operacional que corresponde al concesionario, en modo alguno resulta posible que la modificación de la cuantía de las tarifas tenga por objeto eliminar los déficits o, en su caso, los superávits de la explotación debidos a la evolución de la demanda de utilización de la obra o del servicio.

Resta añadir que la Administración contratante, además del ius variandi, también tiene reconocido el derecho a supervisar la ejecución del contrato y a «resolver las dudas que ofrezca su cumplimiento», estando, asimismo, habilitada

58 En este sentido, véase R. Gómez-Ferrer-Morant (1977), «Legislación estatal en materia de precios y concesiones de las Corporaciones Locales», Revista de Administración Pública, 84, pág. 307. Asimismo, Santamaría Pastor (2021: 158).

59 Véanse SSTS de 23 de febrero de 2001 (rec. 3856/1995), fundamento de derecho 5, y de 2 de junio de 2016 (rec. 827/2014), fundamento de derecho 5. 
para dictar órdenes e instrucciones al contratista, tal como prevé la LCSP en relación con los distintos tipos de contratos [arts. 238.1, 261.1.f) e i), 287.2, y 303], y el ejercicio de estas facultades pueden llevar a que, sin modificar el contrato, el cumplimiento del mismo suponga una mayor onerosidad para el contratista.

No es cuestión ahora, ciertamente, de que nos adentremos bajo qué circunstancias y condiciones la mayor onerosidad será debida a la observancia de órdenes e instrucciones dadas por la Administración. La jurisprudencia refleja, a este respecto, un muy notable casuismo que, por ello mismo, al depender estrechamente de los hechos y pruebas de cada caso, no permite ir más allá de la afirmación general de que tampoco en el riesgo y ventura del contratista queda englobado el riesgo de sufrir posibles perjuicios debidos a decisiones de la Administración contratante. La propia regulación de la responsabilidad extracontractual del contratista por daños a terceros confirma, en fin, que en el riesgo y ventura que asume no están incluidos los daños que pueda causar en el cumplimiento de órdenes e instrucciones dadas por la Administración contratante (art. 196 LCSP).

En cualquier caso, una vez más debería corregirse la actual regulación, ya que no diferencia con la precisión debida entre unos y otros supuestos al referirlos conjuntamente a la garantía del equilibrio económico-financiero de la concesión. En este supuesto de alteraciones debidas a órdenes e instrucciones, la compensación debe proceder por razón sin más de la acción de la Administración contratante, que determina un mayor coste en la ejecución que al contratista obligatoriamente se le impone, a pesar de que, al igual que sucede con las consecuencias derivadas del ejercicio del ius variandi, esa compensación aparezca prevista únicamente al regularse el restablecimiento del equilibrio económico-financiero de la concesión. Todo ello, además, con la particularidad de que no se hace conjuntamente con el supuesto de que la Administración realice una modificación, sino con ocasión del otro supuesto referido a "actuaciones de la Administración Pública concedente, [que] por su carácter obligatorio para el concesionario determinaran de forma directa la ruptura sustancial de la economía del contrato" [arts. 270.2.b) y 290.4.b) LCSP]. De este modo, se mezclan supuestos heterogéneos que no deberían tener el mismo tratamiento jurídico, pues distinta es la causa determinante de la mayor onerosidad.

El resultado final es que, a diferencia de lo que sucede cuando el desequilibrio trae causa de la modificación del contrato, ahora el mayor coste derivado de la necesaria observancia de esas órdenes e instrucciones, en la medida que no encuentra otra cobertura que el supuesto previsto en los arts. 270.2.b) y 290.4.b) LCSP — lo que, por otra parte, obliga a incluir en las «actuaciones de la Administración contratante» el ejercicio de poderes contractuales, distorsionando con ello el supuesto-, solo debería ser compensado, en estrictos términos, cuando se produzca «de forma directa una ruptura sustancial de la economía del contrato», no bastando con que tenga alguna "trascendencia económica». 


\section{LIBERTAD DE PACTOS Y ASIGNACIÓN DE RIESGOS}

A la vista de la regulación legal de la asignación de riesgos en la contratación pública, queda por analizar si esa regulación puede quedar desplazada por la regulación contractual, o lo que es lo mismo, por las determinaciones que, al amparo de la libertad de pactos, puedan acordar las partes contratantes. Todo ello teniendo en cuenta que, en su caso, esas determinaciones vendrán en gran medida dispuestas por la Administración contratante en los correspondientes pliegos de condiciones generales y particulares.

El art. 34.1 LCSP, bajo la rúbrica «libertad de pactos», establece lo siguiente: «En los contratos del sector público podrán incluirse cualesquiera pactos, cláusulas y condiciones, siempre que no sean contrarios al interés público, al ordenamiento jurídico y a los principios de buena administración». Estamos ante una regla que en la contratación pública se viene reiterando, prácticamente en los mismos términos, desde la LCE de 1965 hasta la actualidad ${ }^{60}$, al ser consustancial a la propia institución. La libertad de pactos, unida a la vinculatoriedad de lo pactado, son elementos definidores del contrato, de manera que sin ellos dejaría de ser identificable. No cabe, por tanto, un desplazamiento total o pleno de esa libertad por la norma de derecho objetivo sin que el contrato desaparezca como tal.

Ahora bien, el margen de disponibilidad reconocido por la ley a la libertad de pactos puede variar y resulta lógico que la intensidad de la regulación normativa de los contratos sea desigual según se refiera a la contratación privada o a la contratación pública. La distinta cualidad de los intereses implicados en una u otra explica y justifica que así sea. Cuando se trata de la contratación administrativa, la singularidad de que una de las partes contratantes sea un poder público — la Administración pública- y que, por ello mismo, los intereses implicados en la contratación no sean materialmente equiparables a los de la contratación privada, autoriza a modular o matizar su alcance. De ahí que la libertad pueda quedar más estrechamente condicionada por las determinaciones del legislador, con lo que, según cual sea la intensidad y detalle del contenido regulatorio, los pactos dispondrán de un mayor o menor margen de desarrollo.

La concreción del significado y alcance del reconocimiento de la libertad de pactos en la contratación pública que reconoce el art. 34.1 LCSP depende, en efecto, de la configuración misma de las normas que la limitan. Dicho en otros términos: la libertad de pactos encuentra campo de actuación en todo lo que la ley no define o establece positiva o negativamente, o lo que es lo mismo, en todo lo que la ley no delimita ni concreta. Es ante el silencio, o ante la indeterminación legal, cuando la libertad de pactos resulta operativa. Y también, claro es, cuando la propia norma declara o reconoce como potestativa la observancia de su contenido mismo. A diferencia de lo que sucede en la contratación privada, más allá de

60 Arts. 10, párrafo 1º, LCE de 1965, 4 LCAP de 1995, y 25.1 LCSP de 2007. Todos ellos coincidentes, en lo esencial, con lo que dispone el referido art. 34.1 de la vigente LCSP. 
la indeterminación, o del expreso carácter dispositivo de la norma reguladora, la libertad de pactos encuentra un límite infranqueable ${ }^{61}$.

En la doctrina no otra es la posición que, con carácter general, se viene manteniendo. E. García de Enterría ${ }^{62}$, al comentar el art. 1 de la LCAP de 1995, comienza con esta taxativa puntualización: «El apartado 1 del artículo dispone que los contratos que celebren las Administraciones Públicas deberán ajustarse a las prescripciones de la presente Ley, lo cual tiene una primera y clara intención: la regulación que la Ley contiene no es una regulación dispositiva, aplicable en defecto de la libertad contractual de las partes; es, por el contrario, una regulación imperativa y necesaria, a la que las Administraciones y demás sujetos afectados están positivamente sujetas en tanto que contraten. La libertad contractual procederá únicamente en los casos en que la propia Ley la permita y con los límites que de la misma resultan (los más importantes en los artículos 4 y 49)».

Y la expuesta no es una opinión aislada, ni discutida ${ }^{63}$.

También la jurisprudencia ha mantenido el mismo criterio, si bien algunos recientes pronunciamientos parecen haber olvidado lo que parecía ser una doctrina asentada. La STS de 25 de julio de 1989 (ar. 6114; núm. 1079/1989, ROJ: 4521/1989) acertó a explicar convincentemente el carácter imperativo y, por tanto, obligatorio que, como regla general, presentan las normas reguladoras

61 Resulta evidente, por ejemplo, que la LCSP, al sancionar la regla de que el contratista asume el riesgo y ventura en la ejecución del contrato no define, ni concreta definitivamente, su extensión y alcance. Ni tampoco agota, una vez fijado su contenido mínimo, los casos o supuestos que pueden dar lugar al restablecimiento del equilibrio económico-financiero del contrato. Los riesgos son de muy distinta naturaleza y la libertad de pactos permite, en consecuencia, que su distribución y asignación pueda variar ante cada caso concreto. Jugará, ciertamente, un límite infranqueable, el de que a su amparo no se puede eliminar por completo el riesgo del contratista, al igual que no cabe que los contratantes pacten desvincularse de las excepciones legales que al riesgo y ventura del contratista se hayan establecido. Si la fuerza mayor es un riesgo que la ley excluye del riesgo y ventura del contratista, ¿acaso el pacto permite establecer lo contrario, imputándole a él la mayor onerosidad en caso de hacerse efectivo? O cuando la ley dispone - ahora en positivo- que en el riesgo y ventura del contratista necesariamente se engloba el llamado riesgo operacional, ¿será admisible que la libertad de pactos venga a excluirlo? La respuesta no puede ser afirmativa. Habrá que analizar caso por caso, desde luego, pero, como regla general, no parece que en la contratación pública la libertad de pactos de los contratantes pueda tener la amplitud que se le reconoce en la contratación privada.

62 Véase "Ámbito de aplicación de la Ley (arts. 1 a 9, inclusive)", en R. Gómez-Ferrer Morant (dir.) (2004), Comentario a la Ley de Contratos de las Administraciones Públicas, 2a ed., Civitas, pág. 83.

63 En el mismo sentido, por ejemplo, J. L. Villar Palasí y J. L. Villar Ezcurra (2004b), «El principio de riesgo y ventura», pág. 543, y J. Tornos Mas (2004), «De las actuaciones relativas a la contratación", pág. 286, ambos en R. Gómez-Ferrer Morant (dir.), Comentario a la Ley de Contratos de las Administraciones Públicas, 2a ed., Madrid: Civitas. 
de los contratos públicos. En el fundamento de derecho 6 dejó establecida la doctrina de que, «si bien pudiera parecer que también en derecho administrativo contractual predomina el principio de autonomía de la voluntad, siendo las normas del derecho necesario lo excepcional, [...] semejante conclusión, sin embargo, sería errónea. Por lo siguiente: a) Porque la Ley constituye el límite de la actuación válida de la Administración —artículo 40 de la Ley de Procedimiento Administrativo: «El contenido de los actos se ajustará a lo dispuesto en el ordenamiento jurídico y será adecuado a los fines de aquéllos»- - b) Porque la presunción está a favor del carácter de derecho necesario de esas normas según lo prueba el que cuando el legislador quiere atribuirles carácter voluntario lo dice expresamente (cfr. art. 59 de la Ley de Contratos del Estado sobre ejecución por terceros de determinadas unidades de obras). c) Porque — por lo menos en el ámbito local que es, precisamente, en el que estamos - la primacía de lo normativo sobre lo contractual está expresamente proclamado en el artículo 21.2 del Reglamento de Contratación de las Corporaciones Locales: «el Pliego de condiciones estará subordinado a este Reglamento». Lo que supone que el contrato se subordina a lo normativo — sea norma reglamentaria o legal, sea el Reglamento de 1953 o cualquier otra norma de ámbito general—».

Y aún se añade:

«Esta subordinación de la autonomía de la voluntad a lo normativo que tiene lugar en la contratación administrativa tiene su razón de ser en la necesidad de proteger tanto los intereses de la Administración (normas sobre mora, fianzas, interpretación y modificación de los contratos, etc.), como los del contratista (normas sobre riesgo y ventura, revisión de precios, etc.). Así pues, como regla general las normas sobre el contenido de los contratos administrativo son de derecho necesario y no contractual, a diferencia de lo que ocurre en la contratación civil en que la regla es exactamente la contraria».

La doctrina expuesta ${ }^{64}$ perfila adecuadamente las posibilidades que brinda la libertad de pactos a la vista de la naturaleza que debe atribuirse a las normas legales reguladoras de la ejecución y cumplimiento de los contratos administrativos y, en particular, las que se refieren a la distribución o asignación de riesgos y sus consecuencias jurídicas. Los pliegos tienen, desde luego, un importante campo de actuación para llevar a cabo la concreción del reparto de riesgos, tal como la propia LCSP reconoce expresamente [arts. 250.1.d) y 285.c)], aunque lo tienen dentro del marco regulador que ella misma prevé. Habrá que analizar, por tanto, cada norma en concreto a los efectos de determinar, dada su estructura

64 El señalado no es un pronunciamiento aislado, sino que con anterioridad ya se había mantenido la misma interpretación de que los pliegos quedan sujetos, en todo caso, a las disposiciones normativas aplicables. Baste remitir a lo dicho en SSTS de 21 de diciembre de 1988 y de 26 de septiembre de 1989 (núm. 1662. ROJ: 9079/1988 y 4843/1989, respectivamente), ambas con ocasión de idéntico asunto. 
y contenido, si la misma permite ser excepcionada. Y todo ello desde el criterio general de que, como regla, esas normas son de derecho necesario y no pueden ser desconocidas ni contradichas por los pliegos de condiciones ${ }^{65}$.

Llama la atención, por tanto, que esta doctrina haya quedado silenciada en las SSTS de 1 de diciembre de 2020 (rec. 2408/2019) y de 22 de marzo de 2021 (rec. 4095/2019), al estimar que los derechos económicos previstos en el art. 170.1 LCAP eran renunciables y considerar, por tanto, válida la cláusula contractual que al amparo de la libertad de pactos así lo dispuso ${ }^{66}$. En el fundamento de derecho 4 de la STS de 1 de diciembre de 2020, se afirma lapidariamente:

«No apreciamos en este caso la concurrencia de la excepción al principio general de libertad de pactos que regula el citado artículo 4, pues no se evidencia, ni se ponen de manifiesto solventes razones sobre el contenido de la mentada cláusula 25.1 del pliego de prescripciones técnicas y cláusulas administrativas del expresado contrato, que acrediten o que nos induzcan a considerar que resulta contraria al interés público, al ordenamiento jurídico o a los principios de buena administración».

Y en apoyo de tal criterio se recuerda que en varias sentencias de $2004^{67}$ se declaró también la validez de la renuncia del contratista a solicitar una indemnización en los supuestos de supresión del servicio objeto de la concesión ${ }^{68}$.

65 En este sentido, a propósito de la posibilidad de pactar un interés de demora distinto al fijado legalmente, las SSTS de 29 de octubre de 2018 (rec. 3671/2017), de 14 de noviembre de 2018 (rec. 4753/2017), de 3 de junio, 19 de noviembre y 2 de diciembre de 2019 (rec. 224/2016, 6625/2017 y 6758/2018), y de 21 de febrero de 2020 (rec. 376/2018), han concluido que «desde la Ley 11/2013, de 26 de julio, no cabe un pacto de intereses distinto al fijado legalmente, por lo que los pactos que no responden a lo estatuido en la norma legal se reputan abusivos» y han de ser anulados.

El art. 170.1 LCAP de 18 de mayo de 1995, por relación al contrato de gestión de servicios públicos, estableció que «en los supuestos de resolución, la Administración abonará, en todo caso, al contratista el precio de las obras e instalaciones que, ejecutadas por éste, hayan de pasar a propiedad de aquélla, teniendo en cuenta su estado y el tiempo que restare para la reversión», de manera que, más allá de cuál fuera la causa de la resolución — por tanto, incluso en el supuesto de que fuese imputable al contratista/concesionario-, las obras ejecutadas que pasasen a ser propiedad de la Administración, por esta debían ser abonadas. Véanse J. F. Mestre Delgado (1992), La extinción de la concesión de servicio público, Madrid: La Ley, pág. 293; también J. J. Lavilla Rubira (2006), «El contrato de gestión de servicios públicos en la nueva Ley de Contratos del Sector Público», Documentación Administrativa, 274-275, pág. 275.

67 Concretamente, SSTS de 10 de mayo de 2004 (rec. 138/1994), de 15 de mayo de 2004 (rec. 148/1999), de 21 de mayo de 2004 (rec. 144/1999), de 24 de mayo de 2004 (rec. 220/1999), y de 18 de mayo de 2004 (recs. 136 y 139 de 1999).

68 Hay que advertir que el supuesto enjuiciado en las referidas sentencias se refería a una renuncia de indemnización por la supresión de algunas prestaciones del servicio concedido, lo que, a su vez, había sido pactado que la Administración podría decidir 
Hasta aquí estas dos sentencias que, como se ve, no aportan criterio alguno interpretativo que ayude a determinar cuándo previsiones legales similares a la del art. 170.1 LCAP son susceptibles de quedar desplazadas, sin aplicabilidad alguna, por convenirlo sin más las partes contratantes. Si el derecho que previera el referido artículo es renunciable, ¿acaso no lo serán entonces todos los demás que la legislación contractual reconoce? Como resulta de la más acertada doctrina de la STS de 25 de julio de 1989, bien puede afirmarse que la libertad de pactos se desenvuelve en el marco dispositivo que la legislación contractual haya establecido; nunca cuando la correspondiente previsión legal fija de manera clara y taxativa los derechos y deberes que corresponden a las partes contratantes.

Ahora bien, la libertad de pactos, aun a pesar de las limitaciones a las que potencialmente se enfrenta en la contratación administrativa, no deja de encontrar un amplio campo de desarrollo en orden a la asignación o distribución de riesgos. Como se ha podido comprobar, la vigente regulación resulta sumamente escueta, por lo que, respetando el mínimo legal, los pliegos de condiciones generales y particulares de cada contrato pueden modular ampliamente el alcance y extensión de la regla de que la ejecución de todo contrato lo es a riesgo y ventura del contratista. En tanto esa regulación no se corrija, no otra es la conclusión a la que se puede llegar.

En todo caso, siendo necesario su reajuste en algunos extremos - a mi juicio, en todos aquellos que se han ido señalando a lo largo del estudio-, tampoco conviene que la regulación legal del reparto de riesgos restrinja en exceso el ámbito de la autonomía decisoria de las partes contratantes. La ejecución de los contratos administrativos reclama seguridad jurídica en lo que atañe a la imputación de las consecuencias económicas de los riesgos que puedan materializarse, pero, a la vez, la concreción del reparto de esos riesgos no puede, ni debe, confiarse por entero a la norma legal. Dejar abierto un margen de flexibilidad para que sean las propias partes contratantes las que, dentro del marco legal y a la vista de las particularidades de cada contrato, decidan la más adecuada distribución de riesgos, parece lo más lógico y razonable.

"cuando así conviniera». Un pacto, por tanto, que en nada se oponía a lo dispuesto por el art. 80 LCE de 1965, pues la indemnización que dicho artículo reconocía al concesionario se vinculaba estrictamente a la supresión del servicio acordada unilateralmente por la Administración por razones de interés general —al igual, por lo demás, que en caso del rescate del servicio-, y no cuando la supresión lo fuese al amparo de un acuerdo previo que la habilitase para hacerlo. De manera que, a lo sumo, podría cuestionarse la validez del pacto que permitía a la Administración libremente suprimir parte de las prestaciones serviciales, pero, admitida su validez, no existía impedimento legal a que se pudiese pactar que dicha supresión no se acompañaría de indemnización. 


\section{CONCLUSIONES}

La vigente regulación legal de los riesgos en la ejecución de los contratos administrativos requiere una amplia reforma. Se trata de una regulación que viene reiterándose a lo largo del tiempo. A partir de lo dispuesto por la Ley de Contratos del Estado de 1965, las sucesivas Ley de Contratos de las Administraciones Públicas de 1995 y Leyes de Contratos del Sector Público de 2007 y 2017 prácticamente no han prestado atención a esta fundamental cuestión y se han limitado a reproducir, con ligerísimos cambios, las mismas reglas y, por tanto, a mantener — cuando no a agravar- los mismos defectos e insuficiencias de la inicial regulación. Una regulación inicial, la de 1965, que, por lo demás, en la cuestión que nos ocupa, tampoco supuso cambios especialmente significativos respecto de lo que ya se estableciera en los Pliegos de Condiciones Generales de los siglos XIX y XX (en particular, el Pliego de Condiciones Generales para la Contratación de las Obras Públicas de 13 de marzo de 1903).

La regulación legal puede constreñir la libertad de pactos en orden a la concreción de la distribución o reparto de riesgos, pero no puede pretender desplazarla, vaciándola de toda efectividad. Sin perjuicio de que, por comparación a la contratación privada, en el ámbito de la contratación administrativa esta libertad pueda encontrarse más limitada, su eliminación supondría la desnaturalización de la institución contractual y, sobre todo, resultaría de todo punto inconveniente. La contratación administrativa requiere también de un grado de flexibilidad en función de las características de cada tipo de contrato y, por tanto, se opone a todo exceso de uniformidad. En consecuencia, resulta necesario encontrar un punto de equilibrio en las reglas básicas de distribución de riesgos que, sancionadas a nivel legal y, por tanto, infranqueables a la disposición de las partes contratantes, doten de seguridad al sistema en su conjunto.

En todo caso, esas reglas básicas deben mantener, como eje de la regulación, el tradicional principio del riesgo y ventura del contratista, si bien introduciendo algunas correcciones, ya que la LCSP no concreta adecuadamente la extensión y alcance de la regla del riesgo y ventura del contratista. Solo lo hace al prohibir que, en los contratos de concesión de obras y de servicios, el riesgo de demanda y de suministro - en suma, el llamado riesgo operacional — quede excluido al amparo de la libertad de pactos. Y, de manera negativa, únicamente acota algo esa extensión y alcance al prever las excepciones - y no para todos los contratos- de la fuerza mayor y de las actuaciones de la Administración contratante que provoquen la ruptura sustancial de la economía del contrato.

Pues bien, la regulación de esas excepciones debería ser reconsiderada, al menos, en los siguientes extremos:

a) La fuerza mayor tendría que alcanzar a todos los contratos, lo que en la literalidad de la ley vigente no es el caso.

b) Convendría que en los supuestos tipificados como fuerza mayor se diese cobertura a otros hechos o circunstancias análogos a los actualmente previstos. 
c) Deberían concretarse las consecuencias económicas de la fuerza mayor con carácter general para todos los contratos, eliminando, en todo caso, la desigualdad de que en el contrato de obras todo perjuicio económico, cualquiera que sea su intensidad, da lugar a la compensación íntegra del mismo, mientras que en los contratos de concesiones esas consecuencias solo son efectivas si aquella determina la «ruptura sustancial» de la economía del contrato.

d) En relación con la limitada regulación del factum principis en los arts. 270.2.b) y 290.4.b) LCSP, como supuesto determinante de la compensación al concesionario en el supuesto de que provoque la ruptura sustancial de la economía del contrato, de no eliminarse para reconducirlo sin más al cauce de la responsabilidad patrimonial extracontractual de la Administración y, por tanto, mantenerse como excepción al riesgo y ventura del contratista, sería necesario reformularlo en otros términos a fin de ampliarlo a las actuaciones de "cualesquiera Administraciones» que, en el ejercicio de poderes no contractuales, causan un daño o perjuicio al contratista atendiendo al coste que, de no haber mediado, habría tenido la ejecución del contrato en los términos pactados. Y todo ello por relación a cualesquiera contratos y no solo respecto de los contratos de concesiones.

e) La regla de que las "actuaciones» administrativas no contractuales que por determinar una "extraordinaria onerosidad» pueden dar lugar al desistimiento del contratista habría de generalizarse a todos los contratos en los mismos términos en que lo hacen los arts. 270.4, párrafo $2^{\circ}$, y 290.6, párrafo $2^{\circ}$, LCSP, para los contratos de concesiones de obras y de servicios, si bien corrigiendo la regla complementaria de que el desistimiento no dará lugar a indemnización alguna, a los efectos de reconocer, en su caso, la indemnización prevista por el art. 280.1, párrafo $2^{\circ}$, en relación con el art. 281, ambos de la LCSP.

Sería oportuno explicitar, asimismo, que las consecuencias económicas dimanantes de riesgos imprevistos e imprevisibles solo darán derecho a una compensación por parte de la Administración de acuerdo con lo que, en su caso, se haya dispuesto en el contrato, remitiendo, por tanto, a los pliegos de condiciones la previsión de las condiciones que deben reunir tales riesgos para poder ser indemnizados. Todo ello sin perjuicio de que la propia ley pudiera acotar el margen de disposición en orden a fijar los riesgos imprevistos e imprevisibles compensables y manteniendo, en todo caso, la prohibición de la transferencia a la Administración del riesgo operacional.

Por otra parte, resulta inexcusable el establecimiento formal de la regla de que toda modificación de los contratos que tenga trascendencia económica —en suma, suponga algún daño o perjuicio- da derecho a la correspondiente indemnización, al igual que en el caso del dictado de órdenes e instrucciones de la Administración en la ejecución del contrato. 
Cabe añadir, en fin, que el mantenimiento de la garantía del equilibrio económico-financiero en los términos que resultan de los arts. 270 y 290 LCSP para los contratos de concesiones de obras y de servicios, resulta innecesario, cuando no equívoco, y, por tanto, bien podría prescindirse del mismo. El equilibrio económico-financiero, pese a lo que se suele afirmar en la doctrina y la jurisprudencia, no pasa de ser en su formulación legal sino la suma de unas cuantas excepciones heterogéneas a la regla del riesgo y ventura del contratista — se trata de las ya señaladas de la fuerza mayor, el limitado factum principis, y la indebida inclusión del ejercicio del ius variandi-cuyas consecuencias, además, difieren, por lo que, en puridad de términos conceptuales, carece de sustantividad o especificidad suficiente para caracterizar o singularizar a los contratos de concesiones respecto de los demás contratos. De ahí que pueda prescindirse del mismo, lo que evitaría equívocos y ayudaría a clarificar el sistema de distribución de riesgos.

Podría bastar con estos simples reajustes para dotar al sistema de una mayor seguridad jurídica. Respetando estas reglas básicas, la vía de la libertad de pactos ha de ser el cauce que fije la distribución de riesgos en cada caso. En el bien entendido que, a falta de toda previsión contractual, se aplicarán sin más dichas reglas básicas, sin alteración o desplazamiento alguno por razón de la entrada en juego de otros criterios jurisprudenciales. 
